Portland State University

PDXScholar

$11-12-1996$

\title{
Some Possible Sources of Oral Foreign Language Anxiety (FLA) among Japanese Students in the United States
}

Sawako Yoshikawa

Portland State University

Follow this and additional works at: https://pdxscholar.library.pdx.edu/open_access_etds

Part of the Bilingual, Multilingual, and Multicultural Education Commons Let us know how access to this document benefits you.

Recommended Citation

Yoshikawa, Sawako, "Some Possible Sources of Oral Foreign Language Anxiety (FLA) among Japanese Students in the United States" (1996). Dissertations and Theses. Paper 5204.

https://doi.org/10.15760/etd.7080

This Thesis is brought to you for free and open access. It has been accepted for inclusion in Dissertations and Theses by an authorized administrator of PDXScholar. Please contact us if we can make this document more accessible: pdxscholar@pdx.edu. 


\section{THESIS APPROVAL}

The abstract and thesis of Sawako Yoshikawa for the Master of Arts in TESOL were presented on November 12, 1996, and accepted by the thesis committee and the department.

COMMITTEE APPROVALS :

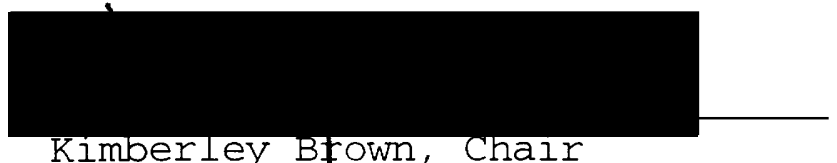

Kimberley Bfown, Chalr
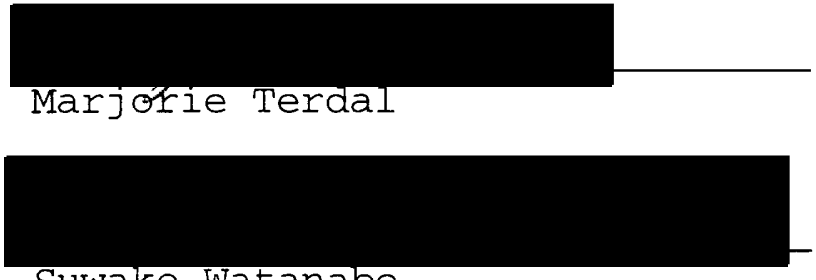

Suwako Watanabe

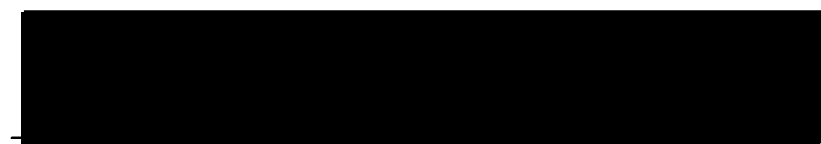

Elaine Limbaugh

Representative of the Office of Graduate Studies

DEPARTMENT APPROVAL :

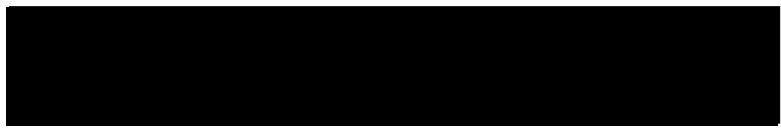

Beatrice Oshika, Chair

Department of Applied Linguistics

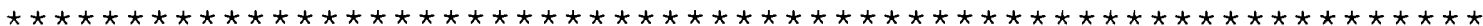

ACCEPTED FOR PORTLAND STATE UNIVERSTTY BY THE LIBRARY 


\section{ABSTRACT}

An abstract of the thesis of Sawako Yoshikawa for the Master of Arts in TESOL presented November 12, 1996.

Title: Some Possible Sources of Oral Foreign Language Anxiety (FLA) among Japanese Students in the United States.

This study attempted to locate some possible sources of oral Foreign Language Anxiety (FLA) among Japanese students in the United States. This study proposed that the following three factors were possible sources of FLA: 1) the subjects' traitlike anxiety, which is carried by individuals across all communication-bound contexts; 2) the subjects' self-perceived oral proficiency levels in English and 3) the subjects' gapsize (i.e., the distance between their self-perceived and their self-expected oral proficiency levels in English). This research examined whether the above three independent variables and the dependent FLA variable were significantly correlated, and if so, which one had the strongest correlation with the FLA variable. Also, whether the subjects' biographical 
variables had a significant effect on their FLA levels was investigated.

All the variables were quantified through a questionnaire. The subjects' FLA levels and traitlike anxiety levels were measured by a 10-item, Personal Report of Communication Apprehension inventory (PRCA, McCroskey, 1978). The subjects' self-perceived oral proficiency levels were measured by asking the subjects to rate their self-perceived oral proficiency level from 1 (poor) to 5 (fluent). The gapsize was quantified by asking the subjects to rate it on a scale from 1 (minimal) to 5 (maximal).

The statistical methodology used in obtaining the PRCA scores in this study differed from McCroskey's in its interpretation of Likert type scales. The scales were treated as interval data in McCroskey's study, while, in this study, they were interpreted as ordinal data. After hierarchically ordering the subjects' answers, non-parametric tests were performed on them. Overall, each of the three variables and the FLA variable were found to be significantly correlated at $\mathrm{p}<.01$. The traitlike anxiety variable, the proficiency variable and the gapsize variable correlated at $.46,-.45$ and -.33, respectively. The participants' demographic variables (age, gender, status at school or year(s) of residence in English speaking places) did not have a 
significant effect on their FLA levels. A discussion of the results was provided, with references to previous studies. 
SOME POSSIBLE SOURCES OF ORAL FOREIGN LANGUAGE ANXIETY (FLA) AMONG JAPANESE STUDENTS IN THE UNITED STATES

\author{
by \\ SAWAKO YOSHIKAWA
}

A thesis submitted in partial fulfillment of the requirements for the degree of

MASTER OF ARTS

IN

TESOL

Portland State University

1996 


\section{ACKNOWLEDGMENTS}

I wish to thank my advisor, Dr.Kimberley Brown, for her overall help.

I would like to express my appreciation to Wes Brenner who worked with me on the statistical analysis; without him, I could not have completed this thesis.

I would like to thank Dr.Kathy Harris, for her information, insight, encouragement and interest.

I am grateful to my family for everything that they have done.

Finally, P.A. Montgomery was there for me at every stage in this thesis, and I would like to thank him. 
TABLE OF CONTENTS

ACKNOWLEDGMENTS $\ldots \ldots \ldots \ldots \ldots \ldots \ldots \ldots \ldots \ldots$

LIST OF TABLES $\ldots \ldots \ldots \ldots \ldots \ldots \ldots \ldots \ldots \ldots \ldots \ldots \ldots$

LIST OF FIGURES .................. vii

CHAPTER

PAGE

I INTRODUCTION $\ldots \ldots \ldots \ldots \ldots \ldots \ldots$

Statement of the Problem ......... 1

Background .............. 2

Research Questions and Hypotheses .. 7

Definitions of Major Terms ....... 9

Summary .................. 13

II LITERATURE REVIEW............... 15

Introduction $\ldots \ldots \ldots \ldots \ldots \ldots$

Defining Foreign Language Anxiety .. 16

Potential Effects of Foreign Language

Anxiety on Language Learning ...... 24

Possible Sources of Foreign Language

Anxiety ................... 32

Summary ................. 46

III $\operatorname{METHOD} \ldots \ldots \ldots \ldots \ldots \ldots \ldots \ldots \ldots \ldots \ldots \ldots$

Introduction ............ 47

Description of Participants ...... 47

Distribution and Collection of the Questionnaire .............. 49 
Design and Development of the Questionnaire .............. 50

Statistical Data Analysis ........ 72

Limitations on Statistical Analysis. 80

Summary $\ldots \ldots \ldots \ldots \ldots \ldots \ldots$

IV RESULTS AND DISCUSSION $\ldots \ldots \ldots \ldots \ldots, 88$

Introduction $\ldots \ldots \ldots \ldots \ldots \ldots \ldots$

Descriptive Statistics ......... 88

Hypothesis \#1 .............. 91

Hypothesis \#2 ............. 97

Hypothesis \#3 ............... 99

Research Question \#4 .......... 103

Research Question \#5 .......... 116

Summary ................ 120

V CONCLUSION .................. 122

Introduction $\ldots \ldots \ldots \ldots \ldots \ldots \ldots \ldots$

Conclusion ............... 122

Implications for Teaching ....... 126

Limitations of the Study and Suggestions

for Future SLA Researchers ........ 133

Summary $\ldots \ldots \ldots \ldots \ldots \ldots \ldots \ldots$

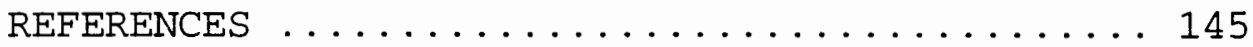


APPENDICES

A Students' Demographic Information ...... 153

B Cover Letter and Questionnaire in English as Administered to the Subjects ....... 156

C Cover Letter and Questionnaire in Japanese ..................... 165

D Question Items Categorized According to Constructs ................... 171

E Factors Influencing Validity Checklist . . 174 


\section{LIST OF TABLES}

TABLE

PAGE

I

Test-Retest Reliability

PRCA in English Contexts ........

II

Test-Retest Reliability

PRCA in Japanese Contexts .......

Descriptive Statistics ........ 89

IV

Gapsize ................... 91

$\mathrm{V}$

Correlations between Each of the Three Proposed Sources and the FLA Levels .................... 104

VI Correlations between the FLA and the NTA Variables .............. 110

VII Correlations between the FLA and the Proficiency Variables .......... 111

VIII Correlations between the FLA and the Gapsize Variables ............ 112

IX Correlations between the FLA and the NTA Variables Categorized along a Continuum of Communication Formality ............... 113

X Correlations between the FLA and the Proficiency Variables along a Continuum of Communication Formality ...... 104

XI Correlations between the FLA and the Gapsize Variables along a Continuum of Communication Formality ........ 104

XII Group Mean Difference among Different Age Groups ............... 117

XIII Group Mean Difference among Genders ............. 118 
XIV Group Mean Difference among the Subjects with a Different status in

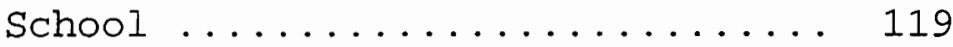

XV Group Mean Difference among the Subjects Whose Residence of $\operatorname{Year}(\mathrm{s})$ Differs ................. 120 
LIST OF FIGURES

FIGURES PAGE

I $\quad$ Gap Construct ............ 12

II Summary of the FLA Sources ...... 39

II Anxiety in Different Situations ... 41 


\section{CHAPTER 1}

\section{INTRODUCTION}

\section{statement of the Problem}

Anxiety about using a foreign language (Foreign Language Anxiety, hereafter, FLA) is one of the factors which individuates people's language learning patterns. Particularly, anxiety about oral production has long been recognized as being a powerful factor in affecting those patterns. The purpose of this study is to locate some of the possible sources of oral FLA among a subset of Japanese students in the U.S.

This chapter identifies the reason why this topic was selected, outlines how the initial interest grew into a set of specific research questions, and provides operational definitions for terms used.

My initial interest in anxiety studies arose from my own experiences as a language learner. During the first few years after I had come to the U.S. I was uncomfortable speaking English and avoided doing so, with the consequence of my learning English taking an unnecessary amount of time. Since then I have been aware that my anxiety is the single largest hindrance to my acquisition of spoken English. Furthermore, other 
language learners have told me that they had also experienced the problem; therefore, I decided to investigate this issue. I have been particularly interested in examining the factors which make people anxious when they speak in their second language.

\section{Background}

Previous studies

McCroskey, Frayer and Richmond (1985a) postulated and tested for the existence of two possible sources of FLA :

1) It has been speculated that the source of FLA may be understood properly as a traitlike property of the learners' which is carried by them across all communication-bound situations. They found that the subjects who generally reported high oral anxiety levels when speaking their mother tongue (native tongue anxiety, hereafter NTA) were also likely to relay that they experienced high oral FLA levels. These research findings may suggest that people's high traitlike anxiety contributes to their high FLA levels; hence, traitlike conceptualization of FLA.

2) The other view argues that the source of FLA is specific to the foreign language learning environment and that the individual learners' FLA level is closely 
related to their proficiency level in their target language. That is, people who view themselves as having low proficiency with the target language tend to be anxious about using the language and the low selfperceived proficiency may be a possible source of FLA.

McCroskey et al. (1985a) examined these two possible sources of FLA and found that 1) the traitlike anxiety argument is a much better predictor of oral FLA than is 2) the subjects' self-perceived proficiency level; hence, their study suggests that FLA should be conceived "as a broad trait-like predisposition" (p.191). However, their study's findings cannot be generalized, for reasons that will be shown in the following argument.

While they believe that their data convincingly supports the conceptualization that conceived of FLA "as a broad trait-like predisposition", I remain unconvinced, because this conceptualization simply contradicts what I believe to have happened in my own language learning experience. When I was learning English in Japan, I was comfortable speaking it and whenever possible, I eagerly used it. It was only after I had came to the U.S. that I became apprehensive when speaking English. I am the same person here and there; thus, I feel that the traitlike argument is at variance with my own experiences. Rather, I think that the other proposed source (i.e., peoples' 
oral proficiency levels in the target language affect their FLA levels) is in more agreement with my experiences.

I believe that McCroskey et al. reached the conclusion they did, while I hold apparently contradictory beliefs, because their subjects' situation and my own situation were distinctly different. Their subjects were Puerto Rican university students in bilingual Puerto Rico and they were in a context where they were able to use their mother tongue as their everyday language. On the other hand, I was in a context where I had to use English day in and day out. If they became too stressed, they had easy access to relief while I had none; therefore, my FLA level and others' in similar contexts, could be more susceptible to being influenced by "the subjects' self-perceived proficiency levels".

Hence, a question was raised as to whether the oral English proficiency levels of Japanese students in the U.S. are correlated with their oral FLA levels as strongly as or more strongly than their NTA levels are. A New Source of FLA Proposed

While the second proposed source of FLA (i.e., learners' self-perceived proficiency level in the target language) seems to be a strong candidate as a source of 
FLA, I believe that, although this argument provides a necessary component, it is not in and of itself sufficient to explain where FLA comes from. I will argue that viewing the "self-perceived oral proficiency" construct as the direct source of FLA is too simplistic. The interplay between people's self-perceived proficiency levels and self-expected proficiency levels (i.e., the level of proficiency in the target language which they believe they should have attained by any given time) needs to be taken into consideration.

This idea also stems from my experiences as a language learner. As mentioned above, in Japan I was not an apprehensive English speaker, even though I knew that my proficiency level was rather low. However, in the U.S. even though my proficiency level improved greatly, I was apprehensive. In a trip to Mexico I experienced something similar. I knew I had little knowledge of Spanish, but I was not apprehensive about trying to use what I did have.

My experiences, upon reflection, led me to the conclusion that expectations of how well I should be able to speak a language must play a role. That is, when I was in Japan, my expectations for my English were low, so I was easily satisfied. My English skills were low, but then so were my expectations; hence, I did not experience 
high FLA levels. However, after moving to the U.S. I raised my expectations to a level which my English skills could not meet. With these two levels out of alignment, I experienced high anxiety. When I was in Mexico, my Spanish skills were low, but it was in line with my expectations; thus, I was not anxious.

Rardin (interviewed in Young, 1992) gave a couple of anecdotes which, taken together, support the idea that learners' expectations need to be taken into account in order to locate possible sources of FLA. In the first anecdote, a learner, who was pre-literate in his mother tongue, showed no sign of anxiety when asked to transcribe a sentence in the target language on to a blackboard. In Rardin's second anecdote, in contrast, he reported that a learner, who was a journalist, complained of how nervous she was when speaking English, as she knew that she could perform very well in her first language and felt that she should be able to do the same in the foreign language. Although one anecdote is concerned with writing anxiety and the other oral anxiety, the point is clear. In the first one, the learner had low expectations and he was not anxious, while in the second one, the learner had high expectations which she failed to meet; therefore, she became self-critical. Therein lies the root of anxiety. 
Thus, the disparity between how well the learners perceive their ability to function in the target language and their expectations is crucial. My own experiences and Rardin's anecdotes argue that when people become anxious it is not simply when they perceive their proficiency as being low, but rather when their expectations exceed their self-perceived proficiency. Therefore, the gap between the learners' (normally low) self-perceived proficiency levels and their (normally high) self-expected proficiency levels is proposed to be another factor which affects people's FLA levels.

In sum, three possible sources of oral FLA were introduced above; two of which came from the FLA literature, and the third was of my own formulation: they are 1) the subjects' oral NTA levels; and 2) the subjects' self-perceived oral proficiency levels in the target language; and 3) gapsize between the learners' self-perceived and their self-expected oral proficiency levels. This research will examine whether each of these three sources and the subjects' oral FLA levels have a significant correlation, and if so, which one has the strongest correlation with the subjects' FLA levels.

\section{Research Questions and Hypotheses}

The following section presents four specific research questions which are elaborations of the previous 
argument, three of which are accompanied by a hypothesis. Additionally, a fifth research question is formulated in order to examine the effects of the subjects' demographic variables (e.g., the subjects' age and gender) on their FLA levels.

Q 1: What is the relation between the subjects' oral FLA levels and their oral NTA levels?

H 1: There will be a significant positive correlation between the subjects' oral FLA levels (as measured by the PRCA-Short Form) and their oral NTA levels (as measured by the PRCA-Short Form).

Q 2: What is the relation between the subjects' oral FLA levels and their self-perceived oral proficiency levels in English?

H 2: There will be a significant negative correlation between the subjects' oral FLA levels (as measured by PRCA-Short Form) and their self-perceived oral proficiency levels in English [measure by asking the subjects to rate their oral proficiency levels from 1 (poor) to 5 (fluent)].

Q 3: What is the relation between the subjects' levels of oral FLA and the gapsize between the subjects' selfperceived oral proficiency levels in English and the subjects' self-expected oral proficiency levels in English?

H 3: There will a significant negative correlation between the subjects' oral FLA levels (as measured by the PRCA-Short Form) and their gapsize (as measured by asking the subjects to rate their gapsize between their selfperceived and self-expected oral proficiency levels in English from [1 (minimal) to 5 (maximal)]. 
Q 4: Which possible source among the three proposed has the strongest correlation with the subjects' oral FLA levels?

Q5: Do the subjects' demographic factors, such as their age, gender, status at school and the length of residence in English speaking places affect the subjects' oral FLA levels?

\section{Definitions of Major Terms}

This section presents the definitions of five relevant terms used in this research.

1) Foreign Language Anxiety (FLA):

An individual's level of anxiety or apprehension associated with either real or anticipated communication with another person or persons in his/ her foreign language with which the individual is not fully proficient.

2) Native Tongue Anxiety (NTA):

An individual's level of anxiety or apprehension associated with either real or anticipated communication with another person or persons in his/her native tongue.

3) Self-Perceived Oral Proficiency Levels in the Target Language:

Regarding this construct, three considerations should be borne in mind by the reader. First, the level of the learners' proficiency is specific to their oral skill. Secondly, the self-perceived proficiency level is 
exactly what an individual perceives it to be. Thirdly, "language proficiency" remains undefined for reasons that will be discussed below.

While defining "proficiency" seems a simple enough task, in fact, it has resisted researchers' attempts to dissect it. The traditional or "received" theoretical framework defines "proficiency" in terms of "linguistic competence" wherein vocabulary, grammar and phonology are held to be paramount. Recent work (e.g., Bachman, 1990; Larsen-Freeman, 1981) has expanded the idea of "linguistic competence" to include how linguistic competence is executed in real situations (i.e., communicative competence) (Verhoeven \& H.A.L. de Jong, 1992) .

While working definitions were given, I still prefer to leave the definition of proficiency open, because, in this study, the pertinent proficiency levels are perceived by the learners. That is, different people believe different criteria must be met, in order for one to be classed as being "fluent". For example, this person stresses ability to exchange ideas smoothly, while that person stresses sounding like a "native speaker". Therefore, as the elusiveness of the learners' selfperceived proficiency has been recognized, it has been left undefined. 
4) Self-Expected Oral Proficiency Levels in the Target Language:

This construct represents an individual's proficiency level in the target language which that particular individual expects should have been reached by the time the question was asked. This construct also has three points; 1) it is specific to oral skill; 2) the proficiency level is a self-expected level as opposed to being a self-perceived one; and 3) the concept of proficiency here is also elusive for the same reasons presented above; hence, it is undefined.

5) Gapsize between the Self-Perceived and the SelfExpected Level of Oral Proficiency in the Target Language:

The gapsize represents distance which an individual language learner perceives to exist between the selfperceived and the self-expected level of oral proficiency in the target language. If the expected level is higher than the perceived one, then there is a negative gap; if the perceived level exceeds the expected level, then there is a positive gap, and when the perceived level is equal to the expected level, then there is no gap. Figure I shows the three types of the gap: 


\section{Positive Gap}

Proficiency level

Higher

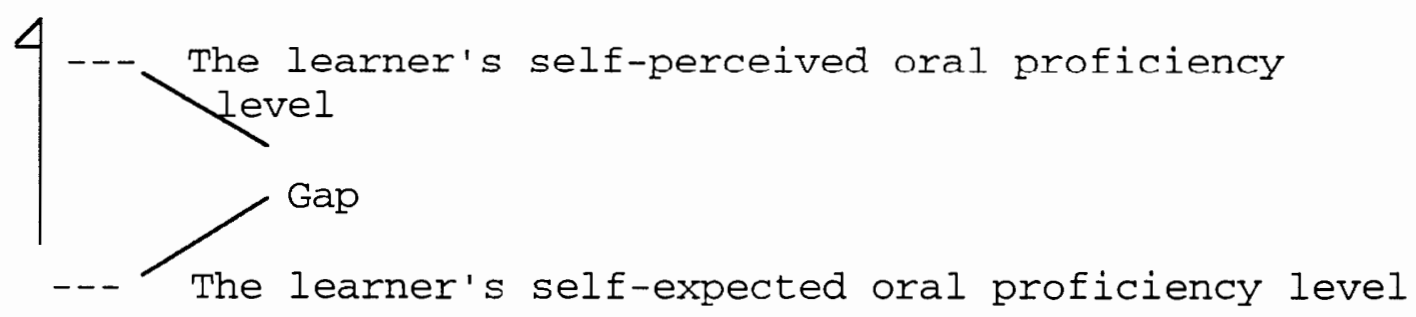

\section{No Gap}

Proficiency level

Higher

-- Both the learner's self-perceived and self-expected oral proficiency level

\section{Negative Gap}

Proficiency level

Higher

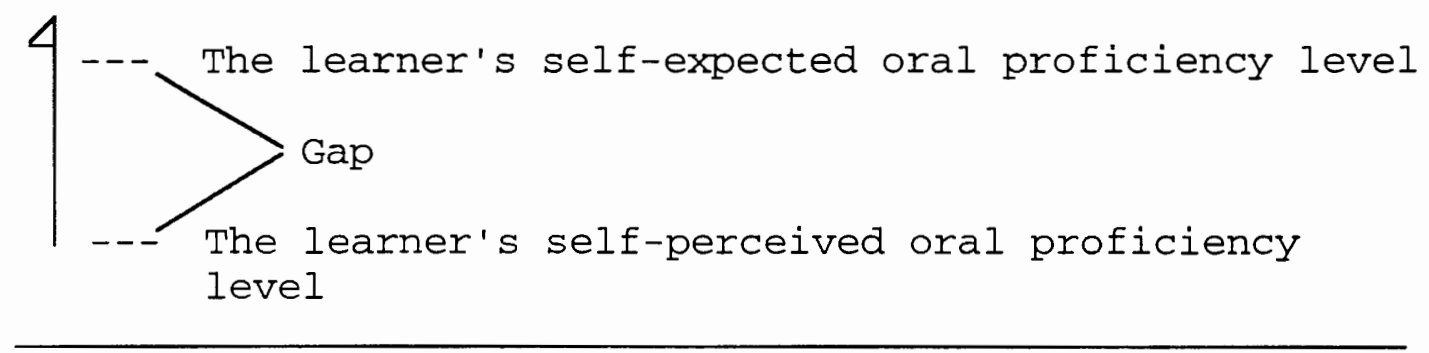

People who perceive the existence of either a positive or a negative gap, were assumed to experience different sizes of the gaps. That is, when the distance 
between one's self-expected and self-perceived oral proficiency level in the positive gap is maximal, people experience a maximal positive gap, while when the distance is minimal, people experience a minimal positive gap. This characterization holds true for the negative gap.

\section{Summary}

This chapter briefly addressed how the examination of possible sources of FLA came to be focused on in this study and then discussed how my interest was developed into a set of research questions and hypotheses. This study examines the correlation between each of the following three possible FLA sources and FLA levels among Japanese students in the U.S.: 1) the subjects' oral NTA levels; and 2) the subjects' self-perceived oral proficiency levels in English; and 3) the gapsize between the learners' self-perceived and their selfexpected oral proficiency levels in English, to see whether a significant relationship was observed between each of the proposed FLA sources with the subjects' FLA levels, and if so, which source had the strongest correlation with the FLA levels. Also, the effect of the subjects' demographic variables (i.e., their age, gender, status in school, and year(s) of residence in 
English speaking places) on their FLA levels is investigated. 


\section{CHAPTER 2}

\section{LITERATURE REVIEW}

\section{Introduction}

Within the field of Second Language Acquisition (SLA) two major paradigms exist which inform research about individual language learner's differences in achieving their goals. One examines cognitive variables such as how general intelligence plays a role in the acquisition of second languages, and the other investigates how affective variables impact those learners.

Among those affective variables, Foreign Language Anxiety (FLA) is interesting for both theoretical and practical reasons; some SLA (Second Language Acquisition) researchers attempt to create a theoretical framework of FLA while some language educators implement anxiety reduction techniques for their classrooms. This chapter will review major issues raised within the FLA literature.

The following is divided into three main components. First, a definition of FLA will be given. This section starts with a summary of Native Tongue Anxiety (NTA) studies and then defines FLA. The summary 
of NTA studies is included in order to 1 ) show the conceptual and empirical framework developed by NTA studies, from which FLA studies have evolved; and 2) to clarify the difference between FLA and NTA, after which, how FLA is manifested will be detailed. Secondly, potential influences of FLA in language learning will be explored by some empirical findings. Lastly, some possible sources of FLA will be discussed.

\section{Defining Foreign Language Anxiety}

Native Tonque Anxiety Studies

Traditionally, anxiety has been viewed as a stable human property, holding sway across various unrelated categories. For example, it was thought that a highly anxious person might be fearful of darkness, heights and snakes. More recently, the conceptualization has shifted to viewing anxiety as holding sway over only similar categories or contexts. Particularly, anxiety experienced in communication-bound contexts is a central concern in anxiety studies and reaches beyond any single discipline. Researchers in the fields of psychology, speech communication and education are broadly interested in this same phenomenon.

However, different researchers focus on slightly 
different aspects and as such, different labels are used to describe similar broadly overlapping phenomena. Some researchers prefer to label these psychological phenomena "apprehension", while others prefer "anxiety", yet the distinction is rather vague and they seem to examine similar constructs. For instance, Spielberger defined anxiety as "the subjective feeling of tension, apprehension, nervousness, and worry associated with an arousal of the autonomic nervous system" (1983, p.34). Zimbardo (1977) uses "shyness" as a tool to investigate people's behaviors characterized by avoidance behavior in social interaction. A construct labeled "Willingness to Communicate" advanced by McCroskey and Richmond (1987) refers to an individual's personality orientation towards talking. Those constructs are not exactly the same per se; however, by including the studies of all related concepts, NTA studies constitute a large body of literature.

There are many theoretical approaches from which to examine NTA. Of those, the two most widely taken approaches are introduced here: the "traitlike anxiety approach" and the "situational anxiety approach". Most of the literature uses the "trait anxiety approach" as the theoretical underpinning for investigating this construct, yet anxiety is not a true trait in the same 
manner as is eye color or sex, so the term, "traitlike", suggested by McCroskey (1984), is used instead. An assumption of this view would be that anxiety is seen as living within people and it cuts across time, receiver, and situation as long as it is bound to communication (McCroskey, 1984); hence, "traitlike". For instance, communication apprehensive people are given various labels, such as "shy" and "reticent". Within the traitlike approach, their communication strategies versus those of non-anxious people's would be examined.

The other approach is the "situational anxiety" approach, in which anxiety is viewed as changing as situations change, rather than as being a static emotion or propensity carried by people into all communication-bound situations that they find themselves in. This approach recognizes that some situations are more anxiety provoking than others. For instance, giving public speeches and singing (in front of others) have been identified as anxiety provoking situations (Leary, 1990).

These two approaches dominate in the field of NTA research and have provided valuable insights into investigating FLA studies; however, FLA is viewed as somewhat different from NTA, and a question remains as to how NTA and FLA are different. 


\section{A Definition of Foreign Lanquage Anxiety.}

In the above, a brief overview of NTA studies [including a definition of anxiety by Spielberger (1983)] was given; researchers have recognized the differences between NTA and FLA and posit that language learners are psychologically more vulnerable than native speakers, as they cannot express themselves as well as they would wish; thus, NTA and FLA should be treated differently. Cited below is Horwitz, Horwitz and Cope's (1991) clear explanation of the differences between NTA and FLA:

Adults typically perceive themselves as reasonably intelligent, socially adept individuals, sensitive to different sociocultural mores. These assumptions are rarely challenged when communicating in a native language as it is usually not difficult to understand others or make oneself understood. However, the situation when learning a foreign language stands in marked contrast... The importance of the disparity between [the] "true" self as known to the learner and [the] more limited self as can be presented at any moment in the foreign language would seem to distinguish language anxiety [from NTA] (p.31). 
As Horwitz, Horwitz and Cope stated, researchers in this field treat FLA as a unique construct. MacIntyre and Gardner (1994, p.285) define it as "the apprehension experienced when a situation requires the use of a second language with which the individual is not fully proficient". In their definition, a lack of mastery of a foreign language is a distinguishing feature of FLA, and as such, their definition clearly separates out FLA from NTA.

Whereas MacIntyre and Gardner's definition is a useful one, it fails to recognize that anxiety is something people think they would experience. This notion becomes particularly important when the construct is measured by reflective self-report types of instruments (i.e., questionnaires). This is the type of instrument employed in this study and in these instruments, subjects are asked to rate their anxiety levels which they think they would experience in a given situation (rather than being placed in a situation and then having some questionnaire foisted on them). It is important then to note that anxiety levels reported by the subjects are the levels which they think they would experience, and not the levels which they actually do experience. Considering that this measures peoples' predictions of their possible future emotional 
states, McCroskey's definition (1985a) for communication apprehension is useful. He defined it as "an individual's level of anxiety or apprehension associated with either real or anticipated communication with another person or persons" (p.186, italics added). Both MacIntyre and Gardner's and McCroskey's definitions will be incorporated in order to define FLA for this research. Here, FLA is defined as an individual's level of anxiety or apprehension associated with either real or anticipated communication with another person or persons in one's foreign language with which the individual is not fully proficient.

Even after separating out FLA from NTA, the concept of FLA is still abstract and vague. The following section better conceptualizes what "FLA" is by examining how FLA is manifested.

Manifestation of Foreign Language Anxiety

FLA may be manifested in one or both of the two following areas: 1) the learner's emotional responses; and 2 ) the learner's physiological responses.

The first area is the learner's subjective feelings. Highly anxious learners perceive experiences in language classrooms as being really stressful and are often even fearful of them. For example, Cohen and Norst (1989) analyzed diaries of adult language learners 
and found that the learners in describing the classroom situation often resorted to emotionally packed terms such as: "embarrassment, trauma, resentment, frustration, victim, and guilt". Also, Price (1991) found similar findings in her interviews. Her subjects described language classes in a variety of terms ranging from "horrible" to "awful". Furthermore, the study by Gardner and MacIntyre (1991b) showed that in a French foreign language class, anxiety was rated significantly higher than in an English or math class by their subjects. These results indicate the unique affective effects of foreign language classrooms on students.

The second one is the subjects' physiological responses. Cohen and Norst (1989) reported from their diary study that "blushing, trembling hands, headache and coronary" were words used to describe language classroom experiences. In addition, language anxiety may be manifested as sweaty palms, nervous stomachs, accelerated pulse rate (Rardin's anecdote, reported in Young, 1992), tenseness, perspiring, palpitation, and sleep disturbances (Horwitz et al., 1991). Those physiological responses in some anxious learners seem reasonable enough to attribute their cause to FLA; however, it may not be that simple. The same type and/or level of physiological arousal may be observed when a 
person is not anxious but rather excited. This multiplicity of possible sources of the physiological changes "muddies the water" for researchers who try to examine the psychological construct FLA, through a close examination of physiological changes. Also, measuring the level of physiological arousal requires special expensive devices which are not readily available at many universities. Thus, FLA studies which employ such equipment are scarce. In fact, all the studies above which reported the physiological changes associated with FLA relied on the subjects' subjective self-reports such as interviews, rather than gathering information through more objective means produced by laboratory experiments. In sum, FLA can be manifested in the individual's subjective feeling and physiological responses, but it may not always be accurate to attribute the individual's physiological responses to manifestations of FLA. As a consequence, some researchers such as MacIntyre and Gardner (1994) and McCroskey (1985a) prefer to define the FLA construct in terms of the individual's subjective feeling, but not in terms of the individual's physiological responses (see MacIntyre and Gardner's and McCroskey's definition of anxiety (apprehension for McCroskey) given above, and compare them to the definition of anxiety given by Spieldberger). Due to the 
above mentioned research difficulties concerning the measuring of FLA on a physiological level, it was decided to exclude such a definition for this study. This in turn, led me to select a battery which measures people's level of communication-bound anxiety in terms of the individuals' feelings only for its operationalization.

\section{Potential Effects of Foreign Language Anxiety on Language Learning}

First, this question will be discussed in terms of the examination of the learner's performance and behavior influenced by FLA and then the examination of FLA development (i.e., how the learners' levels of FLA change as a consequence of external or internal changes made within or around the learner) will follow.

The first area is concerned with the potential influences of FLA on the learner's language performance. Since this area may demonstrate a powerful effect of FLA on language learners, it has drawn the most amount of attention of FLA researchers.

In his review on anxiety research done in the 1970's, Scovel (1978) encountered rather conflicting research results. Bachman (1976) found that within a group of Spanish speakers, the two students who had the most difficult time learning English had the highest and 
lowest measured anxiety levels. Also, Tucker, Hamayan and Genesee (1976) observed that French-Class Anxiety was significantly negatively correlated with one index of performance, but not with three other types.

In addition, Chastain (1975) found a negative correlation between test scores and anxiety in an audiolingual French class, but he found a positive relationship between language anxiety and test scores in other classes. Chastain explained these conflicting results by saying that language anxiety had both a facilitating and a debilitating effect. That is to say that when the anxiety level is low enough, the learners can be more effective learners since language anxiety gives them a kind of attentiveness (i.e., facilitating anxiety). In contrast, high levels of FLA hinder language learning (i.e., debilitating anxiety). This interpretation was tested and supported by Kleinmann (1978), who examined the relationship between the avoidance behavior of certain syntactic structures in English by foreign students and the students' level of facilitating and debilitating anxiety. The results showed that students who scored high on the items that measured facilitating anxiety used various structures in English that other students tended to 
avoid, which supports the idea of a certain level of FLA playing a positive role on language performance. Looking at facilitating and debilitating anxiety as merely opposite poles of an anxiety continuum sufficiently explains the conflicting results produced by the early research; nonetheless, some questions arise concerning this interpretation of FLA. Williams (1991) criticized the vagueness inherent in the above continuum. More to the point, how much FLA is enough to be facilitating and at what point does it become debilitating? In addition, Terrell (interviewed in Young, 1992) questioned whether we should even classify "facilitating anxiety" as "anxiety" and says that he would prefer it to be called "incentive".

A more recent view concerning the relationship between FLA and the learner's language performance focuses on the negative role of FLA in language performance. Many studies show a negative correlation between the level of FLA and proficiency levels as measured by means such as objective tests and course grades. Horwitz (1991) found a significant negative correlation between FLA level and the learner's end of seminar final grade, for beginning Spanish classes and beginning French classes. Also, Ganschow, Sparks, Anderson, Jovorshy, Skinner and Patton (1994) found a 
significant negative correlation between FLA levels and the students' grades over their entire career of college foreign language classes. Other researchers have reported similar results (Clement, 1987; Gardner, Moorcroft \& MacIntyre, 1987; Phillips, 1992; SanchezHerrero \& Sanchez, 1992).

While the results above were obtained in a naturalistic classroom environment, some researchers used a laboratory analogous procedure to investigate the potential cause/effect relationship between FLA and language learning performance. Steinberg and Horwitz (1985) induced FLA in their subjects by treating them "coldly" and videotaping them while they were describing ambiguous scenes in their second language. Also, the researchers had a control group who were treated in a "warm and personal manner", were not videotaped and were asked to describe the same ambiguous scenes. The two groups displayed different degrees of anxiety, with the former induced anxiety group producing fewer interpretive comments. These findings argue that high FLA levels caused people to be less risk-taking in their use of their second language.

MacIntyre and Gardner (1989) investigated the influence of language anxiety in vocabulary learning and production (i.e., Paired Associates Recall and Vocabulary 
Production Test). They found that the subjects with high levels of FLA learned and recalled less than did those with low levels of FLA; they concluded that anxiety may have interfered with the subjects' cognitive efficiency in vocabulary learning.

A second potential effect of FLA on language learning is to cause maladaptive behavioral patterns. Behavioral influences may show up both verbally and nonverbally. Language researchers have observed verbal behaviors such as short responses and nervous laughter produced as a consequence of FLA (Young, 1991). Overstudying for a language class at the expense of other responsibilities, avoiding eye contact and standing outside the door trying to summon up enough courage to enter the classroom (Horwitz, 1989) also have been observed as non-verbal behaviors associated with FLA.

Avoidance behavior is another consequence of FLA. It is a behavior in which a language learner avoids the situation where the use of the target language is required. Such avoidance behaviors can be understood by a more global construct labeled the "immediacy principle", which posits that people are drawn toward persons and things they like, and move away from things they dislike (Mehrabian, 1971). 
Horwitz reports (1989; Horwitz et al., 1991) that some anxious students avoid studying, postpone homework or even skip classes entirely in an attempt to alleviate personal feelings of inadequacy. This avoidance behavior is what I believe to be the most problematical influence of FLA, since it decreases the amount of the learner's use of, and time exposed to the target language. Although language learners may well avoid situations for reasons not concerned with FLA, still I believe that language anxiety triggers avoidance behavior in many learners. The importance of examining the avoidance behavior caused by FLA in language learning is obvious; however, this behavior has been underresearched, in my opinion. That is, many researchers are interested in the more easily observable direct relationship between the level of FLA and language performance, such as correlation between subjects' FLA levels and their grades; however, not many have examined how much of the avoidance behavior is caused by FLA which reduces the contact time of the learner with the target language or contaminates the quality of the contact between the learner and the target language both inside and outside of the classroom; thus, the behavior slows down or hinders their language learning. 
The studies discussed above present a crosssectional/one dimensional relationship between FLA and its effects on language learners. That is to say, these studies examined how FLA influences the language learners at one point of their language learning experience. They are informative; nevertheless, it is also essential to explore developmental aspects of FLA, such as to what extent and how the learners' FLA levels vary over time and/or from one language learning context to another, in order to understand the influences of FLA in language learning. Unfortunately, as far as I know, there is a dearth of studies which document the development of FLA of an individual over time or in different contexts; however, some studies have provided implications to this direction (Clement, Gardner \& Smith, 1977; Desrochers \& Gardner, 1981; Gardner, Smythe \& Brunet, 1977; Gardner, Smythe \& Clement, 1979).

In a 1991a article, MacIntyre and Gardner reviewed some of Gardner's early studies which suggest that the learners' levels of FLA may vary as a consequence of external or internal changes made within or around the learner. Gardner, Smythe and Brunet's study (1977) indicated that increased proficiency in the target language decreases the level of FLA. They found a clear pattern in the French Class Anxiety score among the three 
groups of their English-speaking subjects. Beginners experience the most French Class Anxiety, advanced students the least and the intermediates fall between the two. Also, Gardner, Smythe and Clement (1979), looking at another group of English-speaking language learners, found a similar pattern that as their proficiency with the target language increases, their level of FLA decreases. These studies imply that people's FLA levels decline when their proficiency levels increase.

Furthermore, there is a case in which an external change of the learners seems to affect the subjects' level of FLA. The studies by Clement, Gardner and Smith (1977) and Desrochers and Gardner (1981) found that some language learners who experienced a four-day trip to the target language community showed significantly lower levels of FLA compared to the learners who did not go on the trip. The results may indicate that immediate external changes such as a trip to the target language community may influence the learners' FLA level.

In sum, high FLA levels can be viewed as having maladaptive effects on both language learners' performance and behavioral patterns, and the levels may vary due to internal or external changes of the learners. 
Possible Sources of Foreign Language Anxiety

In the following section, some possible sources of FLA will be examined from the traitlike and the situational approaches, which were originally developed for NTA studies.

The traitlike approach assumes that sources of FLA lie within individuals and focuses on finding what divides anxious people from non-anxious ones. Within this approach, two theories will be looked at: 1) strong traitlike anxiety approach and 2) weak traitlike anxiety approach.

The strong version of the traitlike anxiety approach stresses that FLA is caused by the traitlike communication-bound anxiety of a given person. Thus, in this view, the sources of FLA are not specific to language learning, but they can be explained by the individual's likelihood to be anxious in any given communication situation.

McCroskey et al.'s (1985a) study supports the idea that the sources of FLA lie within people across communication situations, and can be explained somewhat independently from language learning environment. Their study examines communication apprehension experienced in the native tongue (Spanish) and the second language (English) among Puerto Rican students. They found that 
the students who reported that they experienced high NTA levels also tended to be more apprehensive about communicating in English. While they suspected that the self-perceived competence level in the second language would also play an important role in FLA, the study's results show that the apprehension level in their mother tongue is a much better predictor of apprehension in the second language than is self-perceived competence in that language.

Furthermore, Allen et al.'s (1986) study supports the results of McCroskey et al.'s study with a different group of subjects, who were international college students in the U.S. These combined findings support the traitlike conceptualization of FLA in which FLA is seen as being rooted in the individuals' general communication-bound anxiety.

In the field of SLA the sources of the strong traitlike FLA have hardly been investigated, while in Speech Communication the possible sources of communication-bound anxiety, mostly for NTA, have been examined on theoretical and empirical grounds and the arguments seem to be easily applicable to the potential sources of FLA. 
McCroskey (1984) presents two major explanations of the causes of communication-bound anxiety, nature and nurture explanations.

In the nature view, the cause of anxiety is attributed to a genetic source. With this explanation, anxiety is not seen anymore as a traitlike attribute, but rather it is viewed as a distinctive characteristic of individuals; hence, this view may better be labeled the "trait anxiety" approach. This nature view posits that some people are simply born with that property; hence, they are more vulnerable to communication-bound anxiety than others even though they all experience the same environment. Nobody has discovered the "anxiety gene" yet; however, some research has produced promising evidence for the existence of such a gene. McCroskey cited a part from an article by McCroskey and Richmond in order to explain the nature explanation further.

Researchers in the area of social biology have established that significant social traits can be measured in infants shortly after birth, and that infants differ sharply from each other on these traits. One of these traits is referred to as 'sociability', which is believed to be a predisposition directly related to adult sociability the degree to which we reach out to other people and 
respond positively to contact with other people. Research with identical twins and fraternal twins of the same sex reinforces this theoretical role of heredity. Identical twins are biologically identical, whereas fraternal twins are not. Thus, if the differences between twins raised in the same environment are found to exist, biology (heredity) can be discounted as a cause in one case but not in the other. Actual research had indicated that biologically identical twins are much more similar in sociability than are fraternal twins (1980, p.6).

This line of reasoning suggests that some people experience high FLA levels as well as high NTA levels, simply because they have a genetic predisposition to be anxious in any given communication-bound situation.

While the source of communication-bound anxiety is attributed to genetics in the nature view, the nurture view suggests that it is not innately present, but rather some people acquire this traitlike property from their environment. "CA (Communication Apprehension) is a learned trait, one that is conditioned through reinforcement for the child's communication behavior " (McCroskey, 1977, p.80). This behaviorist explanation posits that individuals who, as children, were negatively reinforced regarding actively communicating or were 
positively reinforced for being quiet, will experience high NTA levels.

Furthermore, Klopf (1984) notes that different cultures treat oral communication differently. This culturally saturated view on oral communication influences people's anxiety levels. This phenomenon of oral NTA levels significantly varying cross-culturally has been well documented (Allen \& Andriate, 1984a; Klopf, 1984; McCroskey et al., 1985b; see more detailed discussion in chapter 4 ).

The weak version of the traitlike anxiety approach views FLA specifically related to language learning, but within that context, it also examines the factors which separate anxious language learners from non-anxious learners.

Horwitz (1989) was able to pin down some of the possible sources of FLA to the language learners' preconceived notions about language learning. Compared with the less anxious learners, the more anxious learners tended to believe: 1) that their target language was a relatively difficult language to learn; 2) that some people were simply gifted in language learning and they were not part of this select group; and 3) that in the end, they would not speak the target language well. This study may suggest that the language learners' beliefs 
about language learning play an important role in determining the learner's FLA level.

Furthermore, Foss and Reitze (1988) suggested that the learners' perceptions of their proficiency in their target language must be taken into account when dealing with FLA. They stated that people who are communication apprehensive in foreign languages, "typically have lowself-esteem, perceive themselves as less worthy than others, perceive their communication as less effective than that of their peers, and expect continued failure no matter what feedback they actually receive" (pp.439-440). They also pointed out that the learners' perceptions of their target language competence are complex. They argued that the learners' self-perceived proficiency levels may match with more objective measures of the students' performance, such as the instructor's evaluation, or they may differ. Foss and Reitze cited a part of a journal which was written by one of the best language students in a high-level English class: "But basically I think I'm in low level of the class. That could be a good chance to try to study as hard as I could. Then if I catch up with other students, it shows that I can make progress" (p.440). This example clearly illustrates that the learners' self-perceived proficiency 
levels may not be in line with more objective measures of proficiency levels.

This view is strengthened with the statistical findings of Clement, Dornyei and Noels (1994), who found that the self-evaluated proficiency of the learner is associated with self-confidence with the target language and not with achievement levels as reported by teachers. For a summary of studies comparing the proficiency levels with the target language claimed by the students' selfassessment and measured by more objective measures such as course grades and TOEFL scores, see Blanche (1988).

It is clear that the learners' perceptions of their target language competence should be taken into account when dealing with the sources of FLA.

Generally, studies regarding the sources of communication-bound anxiety treat the self-perception component as a crucial aspect of measuring proficiency or communication competence of subjects' in their native or foreign language, and they consistently found a significant correlation between the subjects' communication-bound anxiety levels and their selfperceived competence levels in that language (McCroskey et Al., 1985a; Allen \& Andriate, 1984). The results of these studies imply that individuals' low self-perceived 
proficiency levels (or communication competence levels) are a possible source of their high anxiety levels.

In the traitlike approach, two views, the strong traitlike and weak traitlike approaches, have been discussed. In the strong version, individuals' high general communication apprehension levels, which could be explained from the nature or the nurture views, were identified as the possible sources of FLA. In the weak version, the learners' set of beliefs regarding language learning and the learner's self-perceived low proficiency levels in the target language are discussed as the potential sources of FLA.

The following figure II summarizes the traitlike approach in explaining the possible sources of FLA.

\section{FIGURE II}

A SUMMARY OF FLA SOURCES FROM THE TRAITLIKE ANXIETY APPROACH

Strong version (sources of FLA live within people) The nature view - The nurture view

Weak version (sources of FLA are rooted in language learning environments)

L Learner's beliefs about their target language learning

- Learner's low self-perceived proficiency of the target language 
This traitlike approach is effective in identifying what divides anxious learners from non-anxious learners; however, it is open to some criticism. Some researchers argue that treating FLA as a traitlike feature is meaningless unless it is considered as reactions within situations. They point out that different people, even those who score the same on a traitlike anxiety measurement battery, find different situations to be anxiety provoking (MacIntyre \& Gardner, 1991b). For instance, even though some studies attempted to isolate FLA to only within speaking contexts, it is not difficult to imagine that some people are anxious when giving public speeches in a foreign language, while others find conversing with a person in that language to be more anxiety provoking.

Figure III, adapted from MacIntyre and Gardner (1991b), demonstrates this point. It is easy to imagine two people achieving the same overall score on a fictional traitlike FLA test, even though those two graded each section, giving public speeches, speaking in a small group, speaking in a class and conversing with a person, differently. Person A finds giving public speeches to be the most anxiety provoking while person $B$ could find talking with another person to be the most anxiety provoking. 


\section{Person A}

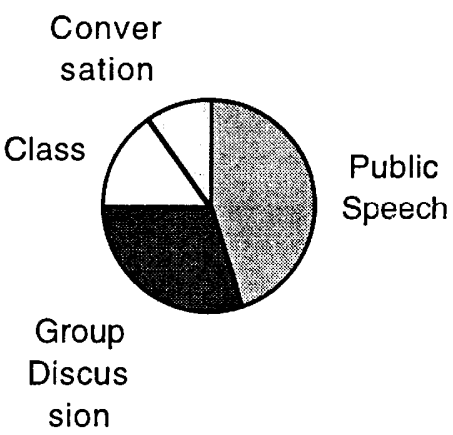

\section{Person B}

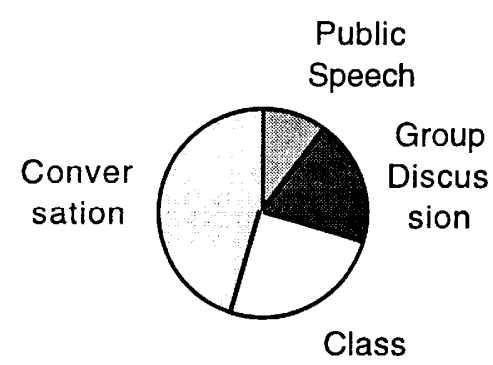

Total

Score

This thought experiment is designed to show that it is the situation which may trigger an anxious response. The traitlike perspective would be blind to the differences in the situations and would merely ask which person is more generally nervous. Below is an outline of a situational approach which resolves this problem.

The situational anxiety paradigm stresses that people's anxiety levels change according to situations in which they find themselves, and this approach examines what situations are anxiety provoking.

The situational approach may look at FLA experienced while using different language skills (i.e., speaking, 
listening, writing and reading). Among those four skills, speaking seems to trigger FLA the most (MacIntyre \& Gardner, 1991a and 1991b; Horwitz et al., 1991; Horwitz, 1989); but some learners also find listening comprehension to be anxiety-provoking (Horwitz et al., 1991; Horwitz, 1989). Horwitz (1989) reported that some students mentioned that they had trouble discriminating the sound and structures or grasping the content of a target language message. In an extreme case, one male student claimed to hear only loud buzzing sounds whenever his teacher spoke in the target language. Also, writing can be an anxiety provoking activity to some individuals (Horwitz et al., 1991).

Furthermore, "speaking", for example, may be deconstructed into discrete skills, some of which may cause anxiety while others may not, for a given person. Horwitz (1989) found in her students' report that spontaneous speaking was probably the most difficult task cited among the anxious foreign language learners, as opposed to being drilled or delivering a prepared speech. However, the learner's level of preparedness for a certain activity alone cannot explain the source of FLA for some individuals. For instance, some anxious students have trouble performing in a role-play situation even though they come to class after rehearsing their 
lines for hours. Also, research by Young (1990) has revealed that students are not afraid of speaking the foreign language so much, but they are afraid of performing some tasks in the language in front of the entire classroom.

Test-anxiety, proposed as one of three components of Horwitz, Horwitz and Cope's FLA model based on language classroom environment, (1991) may shed light on identifying another situation which triggers the language learner's FLA. Test anxiety is apprehension concerning academic evaluation by frequent testing. Horwitz (1989) reported that foreign language teachers often heard students say that they "knew" certain grammar points, but "forgot it" during testing or oral exercises, or that even though students knew the correct answer for a given question, due to their nervousness, they recorded an incorrect answer. Horwitz et al. (1991) are not clear whether this test-anxiety is specific to language class or whether it is more related to a generalized test anxiety; however, the testing situation is an anxietyprovoking situation for many language learners.

After identifying major anxiety-provoking situations in terms of different language skills or various language classroom activities, it seems appropriate to analyze what common characteristics anxiety-provoking situations 
share. Daly's (1991) summary of five characteristics of anxiety provoking situations seems useful here. Although the following theories have been developed in the context of NTA studies, their theoretical tie is obvious to the study of FLA.

1. Evaluation. The more evaluation aspects are involved in a situation, the more the situation is anxiety-provoking. Test-anxiety, discussed above, fits in this explanation. Besides tests, even trivial activities, such as trying to say something in the target language, done in a language classroom seem to have evaluative flavor, and this flavor increases the anxiety level of the students.

2. Novelty. The less familiar the situation and the people involved, the more anxiety is experienced.

3. Ambiguity. The more ambiguous the situation, the more apprehension is experienced. If an individual does not know what is going on in a particular situation, $\mathrm{s} / \mathrm{he}$ is likely to be apprehensive. It is easy to imagine the link of ambiguity to novelty. In many cases people in unfamiliar situations do not follow what is happening and then they experience apprehension. This theory may well explain Horwitz's report that listening may be anxiety-provoking for some learners. Since they do not understand their teacher's instructions in the foreign 
language in the first place, they do not know what is going on, and they do not know what they are supposed to do; as a consequence, they experience apprehension.

4. Conspicuousness. The more conspicuous people feel, the more apprehension they usually experience. Research by Young (1990) mentioned earlier, which found that students are not afraid of speaking the foreign language so much, but they are afraid of performing some tasks in the language in front of the entire classroom can be well-understood from this theory.

5. Prior history. If one particular situation has been negative and has created anxiety in the past for a person, that situation will tend to create apprehension for that person in the future.

Though the sources of FLA can be seen from two different approaches, it is important to keep in mind that those two approaches should not be thought of as two mutually exclusive ways of understanding FLA. Rather, these views should be integrated. Despite the necessity of integrating the two approaches, the situational approach is touched upon only lightly in this study due to several factors (this issue will be discussed later in limitations). However, I will attempt to comment on FLA sources in certain broad given situations. 


\section{Summary}

This chapter reviewed some of the literature concerning FLA, with a special focus on the definition of it, its manifestation in foreign language learners, its effects on language learning and some of its possible sources. It is important to note that anxiety is a psychological construct; therefore, it is not directly observable and as such poses serious problems for researchers defining, manipulating, and most importantly for operationalizing it. Therefore, much more on this subject remains to be explored and without understanding FLA, we are far from creating an environment in which language learning can take place most effectively. 
CHAPTER 3

\section{METHOD}

\section{Introduction}

This chapter describes the method that was applied in the present research. A questionnaire was administered to 232 Japanese students in Oregon, who have been learning English and the data were analyzed statistically to examine the research questions and hypotheses described in Chapter 1.

Below, the method used will be detailed in the following manner: 1) description of the participants, 2) distribution and collection of the questionnaire, 3) design and development of the survey, 4) statistical data analysis, and 5) limitations of data analysis.

\section{Description of Participants}

A total of 232 Japanese learners of English in Oregon participated in this survey voluntarily, and the population pool was not random. In an effort to understand who made up the pool of subjects, demographic information was requested in the questionnaire regarding participants' age, gender, status in school, and year(s) of residence in English speaking places. Tables in Appendix A summarize this information. 
Age

The subjects were divided into three different age groups: 18-23, 24-29 and 30 and over. The majority of the subjects $(155,66.8 \%)$ fell into the 18-23 range, the next largest fell into the 24-29 range $(50,21.6 \%)$ and only 27 people (11.6\%) fell into the 30 and over category.

Gender

The number of women outweighed the number of men in this study, at 150 women to 82 men $(64.7 \%$ and $35.3 \%$ respectively).

\section{Status in School}

The subjects who participated in this study came from a variety of schooling situations as is reflected in the following breakdown of their student status:

1) 89 undergraduate students (38.5\%); 2) 61 ESL students (26.4\%); 3) 41 exchange program students (17.7\%);

4) 19 graduate students (8.2\%); 5) 12 ESL students who also attended regular classes (5.2\%); and 6) 9 "others" $(3.9 \%)$.

Year (s) of Residence in English Speaking Places

The length of residence in English speaking places was divided into four categories: 105 (45.3\%) had spent less than one year; $58(25.0 \%)$ had spent between 4-7 years; 57 (24.6\%) had spent $1-3$ years and 12 (5.1\%) had spent 8 years or more in English speaking places. 


\section{Distribution and Collection of the Questionnaire}

Eight educational institutions and one Japanese association helped in the distribution and collection of the survey throughout the winter term of 1996. Three private institutions, two state universities, three ESL programs and the Japanese association at one of the universities all facilitated the "seeding" of this survey into the classes and social networks of the general Japanese student population.

For each institution, permission to conduct this research was obtained through the appropriate channels; for instance, by obtaining approval from the pertinent Human Subject Research Review Committee (HSRRC) in addition to gaining the approval from the HSRRC at Portland State University, or by finding a sponsor at the target institution.

Generally, the surveys were distributed by instructors in class and from there into the target population's social networks. While distributing the surveys was not difficult, collecting them did pose a problem. It would have been ideal to have the participants complete the surveys within a given time frame, such as during class time, and then collect them in order to have a high response rate; however, obtaining permission to use classroom time for the 
purpose of this study proved impossible, owing to the fact that there were not many classes whose student roster was composed entirely of Japanese nationals. Therefore, in most cases, even though the surveys were distributed in class, the participants answered the surveys at their leisure, and then returned them to the instructors (or contact persons), or returned the surveys directly by mail.

\section{Design and Development of the Questionnaire}

The physical layout of the survey was divided into four sections to both foil attempts by the subjects toguess what the survey actually attempted to measure and to make the survey's directions easy to follow; however, conceptually, it was designed to.investigate the following six different components (See Appendix B for sample questionnaire, whose layout is the same as the one employed in the research, and Appendix D where the questions are categorized according to the constructs examined statistically):

1) the subjects' level of oral FLA (Foreign Language Anxiety);

2) the subjects' level of oral NTA (Native Tongue Anxiety);

3) the subjects' level of self-perceived oral proficiency in English; 
4) the subjects' level of self-expected oral proficiency in English;

5) the gap between the subjects' self-expected and self-perceived oral proficiency levels in English;

6) demographic data on the subjects (e.g., age and gender of the participants).

The following discussion of the survey will be divided in accordance with the above components. Each section starts with a rationale for choosing the instrument for measuring that particular variable and then the contents of the questions will be detailed. Some modifications of the survey items were shown to be needed after a pilot study, and the changes will also be reported. Lastly, a discussion of the validity and reliability of the instruments will follow.

\section{Oral FLA and 2. Oral NTA}

Both the FLA and NTA variables were operationalized by the same PRCA-Short Form, developed by McCroskey in Speech Communication (1978); the subjects' FLA levels were explored in the survey section "When you speak English", and their NTA levels under the "When you speak Japanese" section.

While the following section, which outlines the reasons why the self-report measurement PRCA-Short Form was chosen for this study, may seem too detailed, I believe such a discussion to be important for the reader 
and future researchers to more clearly understand how and why this tool was chosen.

The Rationale for Choosing Self-Report Measurements

For this study I chose the self-report type of measurements rather than the other two commonly used methods, physiological assessment and behavioral observation. In the following, the reasons why this decision was made will be discussed.

1) Self-report measurements

Self-report measurements are able to examine the subject's emotions directly, and are able to inquire into people's affective states that are or would be generated by various displaced situations, which is something that neither physiological response nor behavioral observation are able to do (For more detailed discussion concerning the use of self-report types of instruments for assessing communication-bound anxiety, see McCroskey, 1970, 1986).

2) Physiological assessment methodologies

Because a given set of physiological markers does not necessarily equate to a given affective state (e.g., hearts beat faster due to both anxiety AND excitement) there is a built-in ambiguity to the interpreting of findings gathered in this manner.

3) Behavioral observation methodologies Interpretation of others' behaviors is a famously 
subjective affair. How can an observer legitimately determine whether subjects' not talking in a conversation is a sign that they would prefer to listen, or is symptomatic of a general withdrawal tendency associated with communication-bound anxiety (Lederman, 1983). This leads to the simple conclusion that when inquiring about people's affective states, it is better to ask the subjects directly about their affective states with the caveat in mind that there must be absolutely no reason for them to lie (McCroskey, 1970, 1986).

After weighting the above considerations, I selected the self-report measurements for this study.

The Rationale for Choosing the PRCA-Short Form

In the 1988 article, MacIntyre and Gardner outline 29 self-report type scales and measurements concerning anxiety. Among them, two measurements, 1) the PRCAShort Form and the 2) French Use Anxiety Scale developed by Desrochers and Gardner (1981), were initially selected as models for this research as they satisfied the following four criteria:

1) anxiety type; 2) conceptual well fittedness of the scales to the definition of anxiety used in this study; 3) ease of use; and 4) contexts of questions. 
1) Anxiety Type:

The items should measure speaking anxiety, as opposed to writing or test taking apprehension.

2) Conceptual Well Fittedness of the Scales to the Definition of Anxiety Used in This Study:

The items should not seek to measure the subjects' anxiety levels in terms of their physiological responses due to the interpretation ambiguities discussed above. Therefore, Likert type scale questions such as "I can feel my heart pounding when I'm going to be called upon" (Foreign Language Classroom Anxiety Scale, Horwitz et al., 1991) which inquire about the subjects' anxiety level in terms of their physiological responses are avoided.

3) Ease of Use:

The task required for the participants should be simple and easy, and should not take more than 20 minutes to complete, so as to help to ensure a reasonable response rate.

4) Contexts of Questions:

The scales should be able to measure both FLA and NTA levels; thus, narrowly focused surveys which assess anxiety levels in a language classroom situation are not appropriate, because the Japanese subjects do not attend a language class for Japanese. An example of a type of 
question that should be avoided is "I am afraid the other students will laugh at me when I speak French" from the classroom focused French Class Anxiety Scale [not to be confused with the French Use Anxiety Scale (1985) ] .

After careful consideration, the French Use Anxiety Scale was eliminated, because it asks the individual's anxiety level in a situation which is not a language class, but it hypothesizes a situation in which they are participating in relatively easy communication tasks. For example, one question asks if a person is relaxed or not when talking to a person who speaks the language in question. While such questions seem proper in examining FLA levels, they seem to be inappropriate tools to examine their anxiety levels in their native tongue. After eliminating the French Use Anxiety Scale, the short version of the PRCA was adapted to fill the role of assessing both the FLA and NTA levels.

\section{The Content of Personal Report of Communication} Apprehension (PRCA-Short Form)

In order to understand the PRCA-Short Form, it seems necessary to expand the scope to include two earlier versions of the PRCA-Short Form from which items in the PRCA-Short Form were selected, namely the original 20-item and the 25-item PRCA (MCCroskey, 1970, 1972). In the 
following, a discussion of the two earlier versions precedes that of the PRCA-Short Form, in order to reflect the process of the PRCA series' development. The Original 20-Item PRCA:

The original 20-item PRCA first grew out of a pool of 76 Likert-type scale questions, 30 of which came from Paul's version of Glison's PRCS (Personal Report on Confidence as a Speaker, 1966) and 46 of which came from questions that were written by McCroskey and his graduate students. These items examine anxiety in interpersonal communication, communication in small group settings, and public communication. Also, it contains questions which are not specific to any given context (e.g., I dislike to use my body and voice expressively). After this PRCA was employed on 250 subjects and principal factor analysis and varimatrix rotation were applied to the results, the 20 items with the highest factor loading were selected to compose the original 20-item PRCA.

The 25-Item PRCA:

While the original version has received considerable attention, a consistent criticism was that it was overly focused on public speaking. So, in 1978, McCroskey 
revised the original by adding five new items which were designed to measure dyadic or group communication anxiety .

The PRCA-Short Form:

In the same year that he introduced the revised 25item PRCA, McCroskey also presented a ten item PRCAShort Form, in response to the researchers' desire for a short, but reasonably accurate instrument to measure anxiety. The ten items in the short version were items that were chosen from the 25-item PRCA which had the best item-total score correlations in a sample of 1,183 college students. The correlation between the short version and the long version ranged from .88 to .92 . This short version also uses a five-point Likert scale, from Strongly Agree, Agree, Undecided, Disagree to Strongly Disagree. It contains five negatively worded questions (e.g., "I dislike to use my body and voice expressively") and five positively worded questions (e.g., "I look forward to expressing myself at meetings") .

Some Modifications in the PRCA-Short Form

Even though the PRCA-Short Form has been shown to be highly reliable and valid (to be discussed below), the thesis committee members and six interviewees who 
participated in the pilot study all raised concerns about the validity of the questions employed.

First of all, some commented that a few questions were vague as to how many people were involved in the hypothetical setting supposed by a question. More specifically, ambiguities arose when the items inquired about the subjects' anxiety level either in a "group situation" or a "meeting situation". The crux of the matter is that some people thought that a "group setting" implied more people than a "meeting" does, and others vice versa. In order to avoid this ambiguity, "groups" were specified as consisting of four or five people, while "meetings" were specified as involving twenty people. Also, the meeting setting was changed to a classroom setting since all the subjects are students and it was assumed that it would be easier for them to think about a classroom setting as opposed to a formal meeting. The following shows a few of the example modifications:

\section{Original question A}

I look forward to expressing myself at meetings. Modified question A

I look forward to expressing myself in a class of around 20 people. 
Original question $B$

I am afraid to express myself in a group.

Modified question $B$

I am afraid to express myself in a group of 4-5 people.

Another problem concerned a question which inquires about the subjects' communication-bound anxiety levels when conversing with people (i.e., "I'm afraid to speak up in conversations"). Some people in the pilot study interpreted the question as implying a small group context (2-3 people), while others interpreted it as implying a dyad setting. Therefore, as some other items inquire about the anxiety levels in group settings, it was decided to stipulate that the above question would focus on dyad settings.

Also, the pilot-test subjects pointed out that particularly in a dyad setting, knowing who their interlocutor was was of vital importance in order to answer the question. Thus, a "classmate" as an interlocutor, was added as all subjects have "classmate" relationships, and it was presumed that "classmate" relationships (i.e., not as close as friends, but not as far away as professors) were less idiosyncratic relationship among different individuals. This modification was important because it tries (and succeeds to some degree) to delimit the range of 
possible ways of interpreting this question. The following shows these changes:

Original question

I'm afraid to speak up in conversations.

Modified question

When I talk with a classmate one to one, I'm afraid to speak up in conversations.

Thirdly, a certain question which asks a doublebinding question was modified because the dependent clause in the question entails an assumption. Had a subject rejected (or misunderstood) that assumption, then the answer would have been invalid. Therefore, the dependent clause was deleted. The following shows the specific changes:

Original question

Although I talk fluently with friends, I am at loss for words on the platform.

Modified question

I am at loss for words on the platform.

Lastly, two people indicated that they were unsure whether questions were pointed at their anxiety levels in English speaking settings or Japanese speaking settings, since the same PRCA-Short Form was used to assess the two variables, the subjects' NTA and FLA levels. Initially, directions as to which language was being investigated 
were written at the top of each question set and underlined. However, "redundancy is insurance against mistake" (Miller, 1953, p.8); thus, for each individual question, what language was being focused on was specified. Phrases such as in English, when I speak Enqlish or in an Enqlish speaking setting were added to each question. In the Japanese section, "English" was replaced by "Japanese". The following are examples of the modifications that were made:

Original question

I dislike to use my body and voice expressively. Modified question When I speak English, I dislike to use my body and voice expressively.

\section{Self-Perceived Oral Proficiency in the Target Language}

Rationale for Choosing Self-Report Type Measurement

In order to quantify the subjects' self-perceived oral proficiency levels in the target language, selfreport measurements were chosen since one's "selfperceived proficiency level" is necessarily completely determined by how one perceives it and nothing else. Within chapter 2 there was a discussion about how "objective" criteria, and subjective criteria (i.e., test scores and self-perceived proficiency levels) often 
times do not agree with each other, and as such, this topic is not repeated here.

\section{The Content}

The participants were asked to rate what they consider their current level of English speaking ability to be on a scale from 1 (poor) to 5 (fluent). It has to be noted that the term "fluent" means an overall control over the language in lay terms.

In McCroskey et al.'s study (1985a), which motivated this present study, this variable was assessed by one question; however, in this study it was speculated that only one question measuring the participants' level of perceived English proficiency might not be adequate, since the participants could answer only the question without paying attention. So another question designed to investigate the same construct (but with different wording) was added to compute reliability. Campbell (1968), in fact, wrote that every concept under investigation should be represented by at least two or more questions with different wording.

Moreover, two other items in this section asked the participants about their perceived level of English proficiency in restricted contexts. Each item specifies the hypothetical setting in which the participants are posited to be speaking either with a native or a non- 
native speaker of English. Then each question asks, what individuals think they would perceive their present English proficiency levels to be in that context. These different kinds of settings were selected, as frequently Japanese students mentioned that they could speak English "better" or "worse", depending on to whom they were speaking (native VS. non-native).

Only the first part (i.e., questions which ask the subjects' self-perceived English proficiency level in unspecified contexts) is used as an index of this variable to test the hypotheses (see Appendix C for the questions used in order to quantify this construct), and the other part (i.e., the questions which ask the level in particular situations) is not used for statistical analysis in this study due to certain constraints addressed below.

\section{Self-Expected Oral Proficiency Level in English}

Rationale for Choosing Self-Report Measurement

The choice to use self-report measurements to examine individuals' self-expected proficiency levels of English is made, since the levels are determined by subjects' their own expectation about themselves. The content

In the same manner that the subjects were asked to 
measure the third variable above(i.e., a 5 five point scale, poor to fluent), they were asked to rate what their expected (by themselves of themselves) level of English proficiency was at this time. As in the third section, the items in this section fall into two categories: one asks the subjects' self-expected English proficiency level while the other measures the expected level of proficiency with specific factors borne in mind. An example of a question from the first category would be "What do you think your expected proficiency level should be at this time?" while the second category would be "Thinking about how long you have been studying English, what do you think your expected proficiency level should be at this time?" Informal conversations with various Japanese students and related literature both informed the choice of these factors. The data in this fourth section are not used for the statistical analysis; their function in the survey was to lead the subjects to explicitly think about their self-expected proficiency levels, which are particularly related to the following fifth variable, the gapsize construct. 


\section{Gapsize between the Subjects' Self-Expected Oral Proficiency and Self-Perceived oral Proficiency Levels in English}

Rationale for Choosing the Self-Report Measurements As with the rationale for the above two variables (3 and 4), the gapsize exists within individuals' mind; thus, it seems that the best way to quantify the construct is to ask the subjects about it directly.

\section{The Content}

In order to examine the construct of the gap, the subjects were asked whether they thought there was a gap between their level of self-expected oral proficiency and their level of self-perceived oral proficiency in English. This process had three steps. First, the participants were asked whether there was a gap between their expected and perceived levels of English proficiency. If they responded "yes" to that question, then they were asked whether the gap was a negative one (i.e., the selfexpected level exceeds the self-perceived level) or a positive one (i.e., the perceived level exceeds the expected level), and lastly they were asked to rate the gap size from 1 to 5 (minimum to maximum difference). The possible gapsizes range from -5 to +5 [the expected level exceeds the perceived level to a very large degree (-5) or the perceived level exceeds the expected level to a very large degree (+5)]. 
Some Modifications of the Ouestions

Originally in step 1, which asked whether there was a gap between the expected and perceived levels, there were only two possible answers: yes, there is a gap or no, there is not a gap. However, it became evident from the interviews during the pilot studies, that some people were unaware of whether a gap existed or not. Forcing those subjects to select either a yes or a no would have generated answers that did not accurately reflect their "reality". Thus an "I don't know" option was added in order to better mirror the subject's true perceptions.

\section{The Subjects' Demographic Information}

The following demographic information was sought:

1) age, 2) gender, 3) status in school), and 4) year(s) of residence in English speaking places.

\section{Validity and Reliability of the Instrument}

How trustworthy and how well fitted the instrument is to a particular research purpose is a critical issue for any research design. While the validity and reliability of the PRCA series have been tested extensively since 1970 by various researchers, the newly developed portion of this survey stands in need of more validation beyond the attempts made by this research.

\section{Validity of the Survey}

Broadly, the concept "validity" means "the extent to 
which the data collection procedure measures what it intends to" (Seliger \& Shohamy, 1989, p. 188). The validity of the survey will be discussed below in terms of predictive validity, concurrent validity and construct validity.

\section{Validity of the PRCA}

Predictive Validity:

The concept "predictive validity" refers to "whether the measure can predict accurately a certain future behavior" (Seliger \& Shohamy, 1989, p.190). In the 1978 and 1983 articles, McCroskey examined the predictive validity of the PRCA by measuring whether its empirical findings were consistent with the predictions made by the theory of the construct. The PRCA has been found to be predictive of behavior/choice/orientations across a wide variety of contexts, ranging from where people choose to sit in class, who talks how much in small groups, where people choose to buy houses, to when people decide to marry. The considerable research body based on the PRCA work done, has consistently supported the propositions underlying the theory of communication apprehension. This confirmation supports the predictive power of the PRCA. Concurrent Validity:

The concept "concurrent validity" examines whether the test in question correlates well with different 
instruments which are supposed to measure like

constructs. The PRCA has been tested against several measurements which are supposed to assess similar

constructs. The following significant relationships have been found: the PRCA is correlated at .43 with a unidimensional version of the Unwillingness-toCommunicate Scale (UCS), and an even higher, .69 and .88 correlation with the approach-avoidance dimension of the UCS (Burgoon \& Burgoon, 1974; Burgoon \& Hale, 1983; Daly, 1978).

\section{Establishing Validity for this Survey}

Having already reported on the validity of the PRCAShort Form established by other researchers, a modest attempt to validate this instrument is discussed below.

Construct Validity:

Construct validity is concerned with whether the test items really measure the construct. To ensure validity, in the pilot study, six interviews were conducted with people who had completed the survey, with the help of a Factors Influencing Validity Checklist, which was recommended by Hatch and Farhady (1982, see the checklist in Appendix E). Questions, such as whether the question items provided enough information for the subjects to (correctly) respond to what a given item was intended to ask, or whether one of the provided 
multiple choice answers truly reflected the subjects' condition or situation accurately, were asked. In addition, an attempt was made to ensure that the directions and the layout of the survey were clear, easy and unambiguous, and that the vocabulary used (particularly, Chinese characters presented an issue), and the grammar were appropriate for the population; then some modifications were made as reported above. Reliability of the Survey

The concept of "reliability" refers to whether the instrument is accurate and consistent. As with validity, researchers should be mindful of the different kinds of reliability.

\section{Reliability of the PRCA}

Internal reliability estimates, which examine the consistency of data collection, analysis, and interpretation, have ranged from .87 to .90 for student samples above the 10th grade level (McCroskey, 1978). Test-Retest reliability examines whether the scores are stable over time and it was estimated at a .74 for a sample of 243 college students over a five-week period (McCroskey, 1978). By 1978, this instrument had been administered to 5,000 public school students and 4,500 college students and a normal distribution had been obtained (McCroskey, 1978). 
Reliability of the Survey Established in this Study

If a test is reliable, it produces consistent results across different contexts, such as different time or in different languages. In cases where a test was originally written in a second or foreign language (of the subjects) an important issue, regarding the reliability of the instrument, is how understandable the test is to the target population. This research utilized the PRCA-Short Form, which was originally written in English, so it was translated into Japanese and then back-translated, in an effort to minimize (possible) misunderstandings and to provide an objective check as to whether anything was "lost" in the first translation (see Appendix B for the English version and Appendix C for the Japanese Version). Internal consistency was estimated by examining the correlation between two differently worded questions which inquired about the subjects' self-perceived oral proficiency levels. A high significant correlation was observed (rho $=.81 * \star)$.

Test-Retest reliability was measured $(\mathrm{n}=10)$ over a two to four week period. As table I shows, besides one item (Q6), the correlations for individual items in the PRCA-Short Form in English were significant, and they were highly correlated, ranging from rho $=.64 *$ to $r h o=.97 * *$. These results indicate 
that the items of the PRCA in English, for the ten subjects, were stable over the time period.

\section{Table I}

TEST-RETEST RELIABILITY

Correlation among Individual Items in the PRCA in

English Contexts over a Two to Four week Period ( $N=10$ )

Q1. Q2. Q3. Q4 Q5. Q6. Q7. Q8. Q9. Q10.

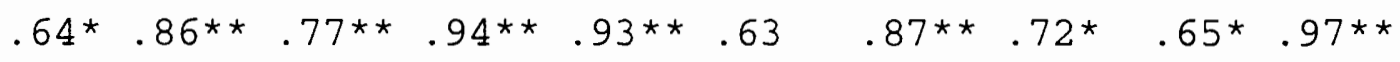

*-Signif. LE .05 **-Signif. LE .01 (2-tailed)

The numbers correspond with the order in the questionnaire (see appendix B)

Regarding the PRCA-Short Form in Japanese contexts, table II illustrates that five items (Qs 1379 \& 10) were found to have no significant relationship, while the other five were found to be significantly highly correlated. These results indicate that over the interval period of time, the scores on some questions were stable and the scores on others were unstable. 
Table II

TEST-RETEST RELIABILITY

Correlation among Individual Items in the PRCA in Japanese Contexts over a Two to Four Week Period $(\mathrm{N}=10)$

\begin{tabular}{lllllllllll}
\hline Q1. & Q2. & Q3. & Q4 & Q5. & Q6. & Q7. & Q8. & Q9. & Q10. \\
45 & $.89 * *$ & .58 & $.96 * *$ & $.76 *$ & $.92 * *$ & .35 & $.83 * *$ & .58 & .50 \\
\hline -Signif. LE & .05 & & $* *$-Signif. LE & .01 & & (2-tailed)
\end{tabular}

The numbers correspond with the order in the questionnaire (see Appendix B)

The correlation for the subjects' self-perceived oral proficiency levels were high (rho $=.70 *$ and $.76^{*}$ ) and the correlation for the gapsize was higher (rho $=.84 * *$ ), meaning that both the scores rated by the subjects for the two variables were, at least, stable throughout the testing time frame.

\section{statistical Data Analysis}

Computation of the Variables

Prior to the application of statistical analyses to test the hypotheses, each variable was calculated in order to produce a single score. As the questionnaire partially replicates McCroskey et al.'s study (i.e., the use of the PRCA series and the measurement of self-perceived proficiency levels with the target language), it was deemed appropriate to follow their steps in order to obtain the scores on those variables. 


\section{PRCA-Short Form}

As mentioned above, the PRCA-Short Form contains ten questions and uses 5 point Likert-type scales anchored at 1 (Strongly Agree) and 5 (Strongly Disagree). A formula to calculate the scores of the items into one PRCA score is provided by McCroskey and is composed of the following three steps:

1. Add the raw scores of items $2,4,5,8$ and 9 , which are negatively worded questions.

2. Add the raw score of items $1,3,6,7$ and 10 , which are positively worded questions.

3. $\mathrm{PRCA}=30-($ total from step 1$)+($ total from step 2)

Basically what this formula does is that it unifies the direction of all the questions by reversing the scores of the five negatively worded questions. The reversing was performed by subtracting each score of the negatively worded questions from six, and then the formula simply adds the raw values of the five positively worded questions and the five reversed values of the negatively worded questions together, in order to produce a total PRCA score for individual cases. While the original method of unifying the direction of the questions by subtracting each score of the negatively worded items from six was well designed, the final step of adding 
those ten numeric values together posed some problems, as will be shown below.

\section{Some Modifications of the Score computation}

In the old PRCA formula, the number values gathered from the Likert type scales could legitimately be added together as long as they are measures of the same dimension (e.g., FLA level), due to the assumption behind the Likert type scales that the "conceptual space", between any two points (e.g., between 1 (Strongly Agree) and 2 (Agree) is equal within a single question item. Also, the space between all the question items is the same as the space between any two points within any given question item.

As a result of this assumption, McCroskey et al. used parametric tests. Parametric tests are more powerful than non-parametric ones (i.e., parametric tests have a lesser chance to make an error in rejecting or accepting null hypothesis than non-parametric tests, Hatch, 1991, p.239). Equal interval data is advantageous for researchers as that level of data is necessary (but not sufficient) for the application of parametric tests. Nevertheless, after consultation with professionals, the interpretation of the Likert type scales was rejected for the purposes of this study. While the proper interpretation of Likert type scales is 
the subject of debate within the research community, here they will be considered as ONLY measuring a position of a score in relation to other scores in the particular item; hence, Likert type scale gathered ordinal data.

The following example question, taken from the questionnaire used in this research, illustrates the point that Likert type scales should be treated as ordinal data. The scale ranges from 1 to 5 (1. Strongly Agree, 2. Agree, 3. Undecided, 4. Disagree, 5. Strong Disagree).

Question 1: I look forward to speaking in public.

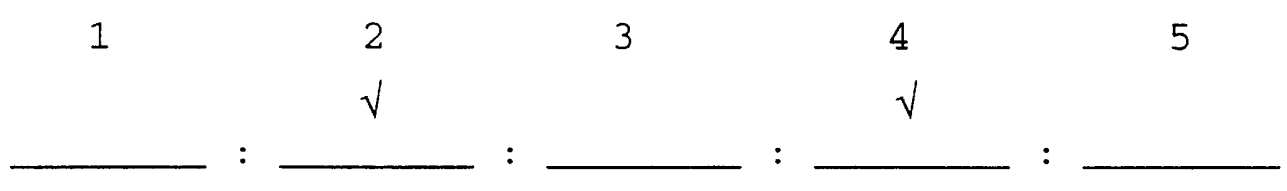

If person A marks 2, and person B marks 4 on a given question, it would seem that the numeric values do not necessarily show that both $A$ and $B$ agree and disagree (respectively) with the question to the same degree. However, the interval interpretation of the Likert scales assumes that the strength of $\mathrm{A}$ and $\mathrm{B}$ 's convictions about the question are the same, because their values are equidistant from "3".

For Likert-type scales (wherein different conceptual distances lie between the points) it has been convincingly 
argued that using numeric values to represent scores is misleading and that, especially, adding raw scores from different questions, as is done in the original formula of the PRCA, is an invalid practice.

Imagine adding the numeric values of the Likert scales on two different questions, whose scales may represent distances between the scales differently. In the following two imaginary scales, the "actual" distance of the scales (i.e., the different perceptual distance between the scales) is expressed by the different visual length between the scales, and the numeric values of the Likert scales are also given. If person A marks 2 on both questions, and then you try to add the two scores in both the numeric way and the "actual" way; even though the sum of the numeric values is "4", the sum of the "actual" distance would be more than "5". Clearly, this is problematic.

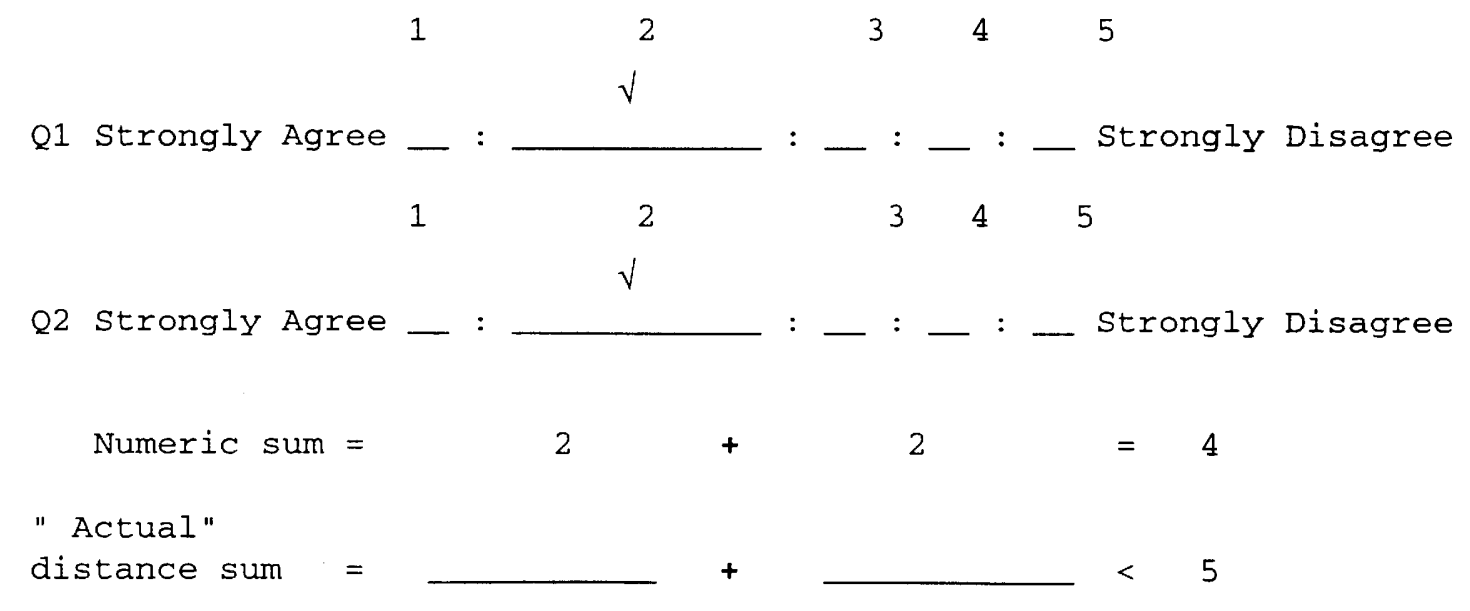


Since the data are treated as ordinal, each raw score was ranked in relation to other raw scores for each given item. "Rank" here is a hierarchical rather than a quantitative concept wherein a person's score on an item is "more than", "less than" or "equal to" another person's score on that same item. The relationships between the people will be expressed in numeric terms with the person who has "more than" being ranked at number 1 and the person who has "less than" being ranked at number 2 .

Once the rankings are enumerated, they are treated as (a type of) interval data whose scales stand for people, and the scales are held to be the same throughout the question items; thus, the ranked numbers generated by different questions are legitimately addable.

However, the reader should not confuse this with the interval data interpretation of the Likert scale which purports to represent conceptual distance. In sum, in the first case, distance between the scales stand for people. In the second case, distance between the scales stands for conceptual distance.

In short, people's relative position to each other is represented through numbers (hereafter "ranked numbers") . Then the new ranked numbers were added together to obtain the total score of the PRCA. 
However, before adding the ranked numbers of the ten questions to find the total PRCA score, each of the ranked numbers was subtracted by 1 and then divided by the number of the observations minus 1 . The number thus generated is labeled the "standardized ranked number".

The formula is:

Ranked Number -1
The \# of Observation -1 Standardized Ranked Number

Through this process, the missing values within an item across observations can be corrected and the new standardized ranked number ranges from 0 to 1. Each of the ten questions of the PRCA has its own standardized ranked number. Those ten standardized ranked numbers are then added and that number is divided by ten (since there are ten questions) in order to produce the total score of the PRCA. This last step is necessary because this process makes it possible to correct for missing values across questions for a single observation. In sum, the steps for calculating the total score of PRCA-Short Form are:

1. Unify the direction of the question by subtracting each raw value of negatively worded items from 6 .

2. Rank each value in relation to other values on the items. 
3. Subtract 1 from the ranked number and then divide it by the number of the observations minus 1 to produce a standardized ranked number.

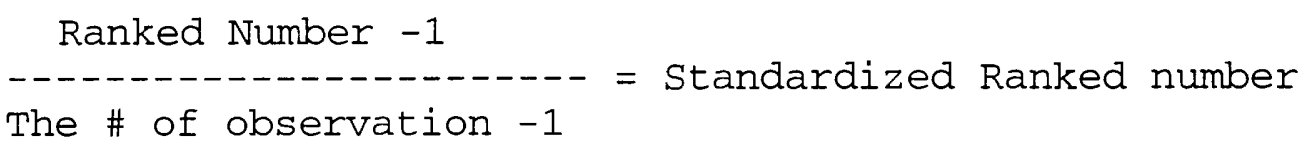

4. Add the standardized ranked numbers and then divide it by the number of the questions answered by each observation in order to produce the total score of the PRCA.

\section{Other Types of Scales Used in this Survey}

There were two other types of scales used for this research; one asked the participants to rate their perceived and expected proficiency level in English, from 1 to 5. (or poor to fluent) and the other assessed how big the gap was between the participants' perceived proficiency level and the participants' expected proficiency levels on a scale ranging from 1 to 5 (or a minimal difference to a maximal one). In this study, the data gathered from those items are considered ordinal data, for the same reasons that the Likert scales are treated as ordinal data. Therefore, the same computation to obtain scores from those scales is performed by ranking those raw values and then standardizing them, as detailed above.

\section{Statistical Analysis}

The data in this study did not meet the assumptions for the use of parametric tests: 1) the sampling was not random; 2) the data cannot assume a normal distribution; 
and, 3) the data under comparison did not exhibit equal variances. Therefore, nonparametric tests were applied (Norusis, 1988, 1992). The SPSS package 6.1. version (1994) was used for the analyses.

In order to test correlations between the dependent variable and each of the three independent variables (Hypotheses 1, 2, 3 and 4) Spearman's rho correlational analyses were used.

The Kruskal-Wallis test was applied to examine the between group difference with two or more groups and the Mann-Whitney test to the between group difference with two groups. The following four factors: the participants' age, gender, status at school and the length of residence in English speaking places were examined to find whether the difference in the subjects' demographic information affects the level of their FLA levels (Hypothesis 5).

\section{Limitations of Data Analysis}

The conceptual shift regarding the data interpretation of Likert type scales, detailed above, limited the possible choices of data analyses that could be performed in this study. While the above discussion of data analyses is still fresh in the readers' mind, the topic of limitations of data analysis will be presented here. 
Originally, the assumption behind the Likert type scales had been that the "conceptual space", which is represented as a line in the picture below, between any two points [e.g., between 1 (Strongly Agree) to 2 (Agree)] is equal within a single question item. Also, the space between all the question items is the same as the space between any two points within any given item.

Strongly Agree

12

Q. 1

Q. 2

Q.3
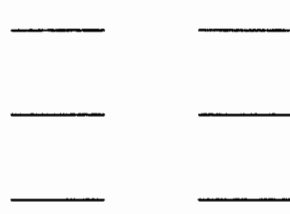

Strongly Disagree

3

4

5
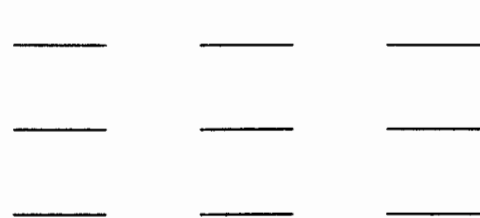

Thus, the scores obtained from different questions were considered to be addable, as long as the questions inquired about the same dimension (e.g., FLA levels), and the score between any two question items could have been legitimately compared. However, after the data had been gathered, the professionals with whom I conferred, successfully argued, for the reasons outlined above, that the data ought to be conceived of as ordinal data.

A major problem imposed by the (new) interpretation of the Likert type scales was that the scores, of any given question item, were held to be incompatible with the scores from different questions, and this 
incompatibility held true for the scores within both the raw scores and within the "ranked numbers".

The raw scores were held to be incompatible due to the fact that each different question imposed or implied different situational constraints from other questions. An example may make this point clearer. Given the following two questions, one could easily imagine that an American would select "1" for the first question, and something other than "1" for the second.

Q1: Mikhail Gorbachev's English ability is excellent: (Strongly Agree) $14 \quad 2 \quad \begin{array}{lllll}3 & 4 & 5 & \text { (Strongly Disagree) }\end{array}$ Q2: Bearing in mind your mother's English ability, Mikhail Gorbachev's English ability is excellent: (Strongly Agree) $1 \quad 2 \quad 3 \quad 4 \quad 5$ (Strongly Disagree)

With the above example in mind it is possible to see that the conceptual area covered by one question is different from the conceptual area covered by another, the point being that the scores of different questions cannot be meaningfully compared as each question item decides its own conceptual area.

The reason why "ranked numbers" are held to be incompatible is that they are obtained by assigning a number which reflects that score's hierarchical position relative to other subjects' scores on the same item.

In the following, the limitations will be detailed by examining what kind of analysis became impossible for 
a particular variable.

Subjects' FLA and NTA Levels Measured by the PRCA-Short Form

The PRCA is composed of ten items which quantify the subjects' FLA and NTA levels in different kinds of communication situations, such as in group or public speech settings. With the initial interpretation of the Likert type scales (i.e., the scales are equal interval within a single question item and throughout all question items, and the conceptual area covered throughout all the questions is the same), it would have been possible to describe how different kinds of communication situations can evoke different degrees of FLA (and NTA) as well as to compute the total score of FLA (and NTA) for each subject. For instance, it would have been possible to compare central tendencies of the subjects' FLA levels in different communication contexts (e.g., compare the mean of the "group settings" and the mean of the "public speech settings") and the differences in the tendencies would show which situation was perceived by the aggregate of the subjects, to be more anxiety producing. However, the new data interpretation assumes that comparisons utilizing any central tendencies of two questions are meaningless, as the conceptual area changes in accordance with each question's own constraints. 
With the ranked numbers in each question now being seen as a relatively autonomous entity, the incompatibility of using central tendencies makes both of the following impossible: 1) comparisons between the ranked numbers from any individual question items and 2) comparisons between any added ranked numbers (that is, the total scores of the ranked FLA and NTA). Therefore, the ranked FLA and NTA scores cannot usefully be compared against each other, and so whether one or the other was higher became an unaskable question.

There was a correlational analysis available, which allowed an investigation into the relation between two question items; however, that analysis only allows people to observe whether the same individuals who find group settings to be more anxiety provoking than other people do, also find public speaking to be more anxiety provoking than other people do. What it does not tell people is which setting is the more anxiety provoking. The new assumptions behind the Likert type scales severely limited the scope of this research by precluding the examination of anxiety from a viewpoint which presupposes that different situations provoke different degrees of anxiety (i.e., the situational anxiety approach) .

Finally, due to the relativity of the ranked 
numbers, the data obtained by this research are incompatible with the data obtained in previous studies which utilized the very same PRCA. The Subjects' Self-Perceived oral Proficiency

A problem regarding the subjects' perceived proficiency level was concerned with questions which examine the subjects' perceived proficiency levels with different interlocutor cues (i.e., talking to a native speaker or a non-native speaker of English). Another problem, similar to the one described above, is that the new assumptions behind the Likert type scale make it impossible to compare the central tendencies of any two questions meaningfully before or after ranking; thus, describing with whom the subjects perceived their proficiency to be higher, became impossible.

The Gapsize between the Subjects' Self-Perceived and Self-Expected Oral Proficiency Levels

Originally in the survey, the gapsize between the subjects' self-perceived proficiency levels and their self-expected proficiency levels was designed to be quantified in two ways in order to examine the subject's conceptualization of the gap in more depth, as well as to compute reliability of the questions: 1) ask the subjects directly to rate their gapsize from 1 (minimal) to 5 (maximal); 2) have the subjects rate their self-expected 
proficiency level and self-perceived proficiency levels from 1 (poor) to 5 (fluent) independently and then subtract the raw score of the subjects' expected proficiency level from the raw score of their perceived levels in order to compute the gapsize. However, with the ordinal interpretation of the Likert type scales the second manner was not an available option as the raw scores of two questions have to be ranked individually before any comparison can take place. After they are ranked, the problem of relativity of the "ranked numbers" invalidated the subtraction process in which one "ranked number" is subtracted from another.

In short, due to the new data interpretation, this research had to bear some extra limitations. However, I believe that I made a right choice as a researcher and the change did have the felicitous effect of A) strengthening, through adversity, this thesis, and B) forcing me to examine, in depth, what assumptions are made by what interpretations.

\section{Summary}

This chapter outlined the quantitative research method utilized in this study in terms of 1) description of the participants, 2) distribution and collection of 
the questionnaire, 3) the development of the survey, 4) the statistical data analysis, and 5) limitations of data analysis. The next chapter will report the results of statistical analyses and then present interpretations of them. 


\section{CHAPTER 4}

\section{RESULTS AND DISCUSSION}

\section{Introduction}

The purpose of this chapter is to present the results of the statistical analyses and discuss them in relation to each research question and hypothesis one at time. The order of the presentation will be, 1) restatement of each research question and/or hypothesis; 2) presentation of the results obtained in this study; and 3) discussion of the results, with reference, where available, to previous studies.

\section{Descriptive Statistics}

Table III provides descriptive statistics for the following four variables, which were utilized in performing the correlational analysis: 1) the subjects' oral FLA levels, 2) the subjects' oral NTA levels, 3) the subjects' self-perceived oral proficiency levels, and 4) the gapsize between the subjects' self-perceived oral proficiency levels and the subjects' self-expected oral proficiency levels. 
It should be noted that due to the ordinal interpretation of the Likert-type scales, all the variables were ránked and standardized from 0 to 1 (discussed in chapter 3). Therefore, all their scores averaged out at .50; as a consequence, the means obtained in this manner convey no useful information. While each ranked variable's possible range (i.e., their minimal and maximal value) is from 0 to 1 , the actual range spanned did not vary strictly to that range, as the same ranking was assigned to ties.

TABLE III

DESCRIPTIVE STATISTICS

\begin{tabular}{|c|c|c|c|c|c|}
\hline & Mean & $\begin{array}{c}\text { Std } \\
\text { Dev }\end{array}$ & Min & Max & $\begin{array}{c}\text { Valid } \\
\text { N }\end{array}$ \\
\hline FLA Level & .50 & .17 & .13 & .90 & 232 \\
NTA Level & .50 & .16 & .15 & .85 & 232 \\
S-P Level* & .50 & .28 & .08 & .96 & 232 \\
Gapsize & .50 & .29 & .08 & .99 & 195 \\
\hline
\end{tabular}

* Self-perceived proficiency level

The following frequency data is also given regarding the gapsize. The gapsize was assessed by utilizing a three step question: 1) whether the gap exists or not; 2) whether the gap is positive or negative; and 3) how big is 
the gap. Table IV summarizes the frequency data of the three step question.

Concerning the first question, which inquired whether the subjects perceived a gap or not, 156 (67\%) people responded that they thought there was a gap, 39 (17\%) perceived no gap, and the remaining $37(16 \%)$ reported that they were not sure whether there was a gap or not.

The second question examined the direction (positive or negative) of the gap among the subjects who answered yes to question 1 . The majority of the subjects (137/156, 88\%) reported that they perceived a negative gap (i.e., their expected proficiency levels exceed their perceived proficiency levels), while 19 individuals (12\%) recorded that they experienced a positive gap (i.e., their perceived proficiency levels exceed their expected proficiency levels).

There were eleven possible responses to the third question which inquired about the gapsize, ranging from a maximal negative gap of -5 to a maximal positive gap of +5. The subjects ranged themselves in a clumpy population distribution pattern, wherein the population tended to cluster at certain values. $62.1 \%$ (i.e., the sum of the percentages found at $-3,-4$ and -5 ) of the subjects perceived themselves as having a relatively large negative 
gap ranging from -5 to -3 and $20 \%$ of them clustered at 0 (no gap). Only 10.1\% maintained that they perceived a positive gap and within the positive gap continuum, the population was rather equally distributed at each value (note: the 37 people who answered "I don't know" whether I perceived a gap or not, were not included in the calculation of the percentage for the third question).

Q1. Is there a gap?

$\begin{array}{ccc}\text { I don't know } & \text { YES } & \text { NO } \\ (16 \%) & (67 \%) & (17 \%)\end{array}$

Q2. Is the gap positive or negative?

$$
\begin{aligned}
& \text { Negative or Positive } \\
& (88 \%) \quad(12 \%)
\end{aligned}
$$

Q3. How big is the gap?

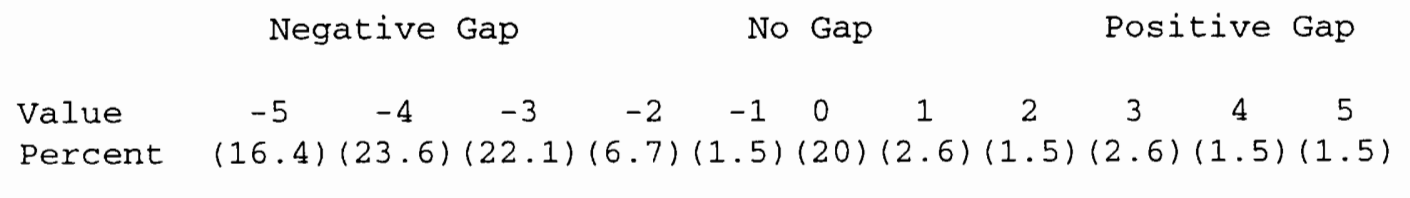

\section{Results and Discussion}

Research Question and Hypothesis 1

Q1: What is the relation between the subjects' levels of oral FLA and the subjects' levels of oral NTA ? 
H1: There will be a significant positive correlation between the subjects' levels of oral FLA (as measured by the PRCA-Short Form) and the subjects' oral NTA (as measured by the PRCA-Short Form).

There was a significant moderate positive correlation (rho $=.46 ; \mathrm{p}<.01$ ) between the subjects' oral FLA and oral NTA levels. As hypothesized, the results showed that the subjects who were more anxious about speaking Japanese also tended to be more apprehensive about speaking English and subjects who were less anxious when speaking Japanese also tended to be less apprehensive while speaking English.

The results support previous studies, in which a significant positive correlation between the subjects' oral FLA and NTA levels were observed (MCCroskey et al, 1985a; Allen \& Andriate, 1984a; Allen et al., 1986a ) and strengthen the view that FLA and NTA are related, and that the subjects' communication-bound anxiety levels may affect their FLA levels.

Due to the fact that the Likert-type scales were treated as ordinal data in this research, it was impossible to determine which anxiety levels (FLA or NTA levels) were higher. However, in previous studies it was found that the subjects' FLA levels were higher than their NTA levels, and it was speculated that the subjects' NTA 
levels set a base line for their FLA levels (Allen \& Andriate, 1984b; McCroskey et al. 1985a; McCroskey et al. 1985b). This line of reasoning suggests that a firm understanding of people's NTA levels would play an important and beneficial role for researchers of FLA studies.

The phenomenon of oral NTA levels varying cross-culturaliy has been documented (Allen \& Andriate, 1984b; Klopf, 1984; McCroskey et al. 1985b). Klopf (1984) found that the NTA levels of his Japanese subjects were the highest, significantly, out of a pool of subjects which was composed of people from the U.S., Australia, the Philippines, Korea, Micronesia, and the People's of Republic China. Moreover, McCroskey et al.(1985b) also compared their Japanese subjects' NTA levels and their Puerto Rican subjects' NTA levels. The Japanese subjects exhibited much higher levels of NTA; $72.6 \%$ of the Japanese subjects were categorized as being "high apprehensive" [sic] while only $10.5 \%$ and $11.8 \%$ (sample 1 and sample 2, respectively) of the Puerto Rican subjects were categorized as being in the high "anxiety category". Also, none of the Japanese were rated as being "low apprehensive"[sic] as opposed to $32.4 \%$ and $27.9 \%$ (sample 1 and sample 2, respectively) of the Puerto Rican 
subjects. To summarize the studies, the Japanese studied might be described as highly apprehensive regarding oral communication even in their native tongue, when compared with other nationals studied.

Generally, attempts have been made to explain the high oral NTA levels observed among Japanese with the "nurture explanation" (i.e., attribute the cause of the phenomenon to its environment rather than its innateness). More exactly, Japan's cultural views on oral communication which downplay the role of speaking are often considered as a leading factor of the people's high NTA levels. In the articles by Klopf (1984) and Lucus (1984), cultural views, such as [Japan's]" culturally shared mistrust of words" (Lebra, 1976) or "a talkative person can be considered to be "show-off" or "insincere" (Rogers \& Izutsu, 1980) are introduced in order to support the view that the Japanese culture downplays the role of speaking; hence, the people tend to be highly apprehensive during oral communication.

Furthermore, Yamamoto (1991) reported from her interviews that most of her Japanese student subjects expressed negative feeling toward "self-assertiveness" and felt "uncomfortable" towards people from different cultures who expressed their opinions in an "aggressive 
manner", in whole or group discussion settings (p.107). Her findings suggest that the Japanese subjects dislike/disapprove of "self-assertiveness" expressed by speaking out in class or group settings, and are uneasy in performing/behaving in a manner which they themselves perceive to be "self-assertive" or "self-aggressive".

Moreover, the Japanese student's comparative lack of experiences in speaking aloud in class or in other semiformal contexts, combined with a Japanese cultural imperative that minimizes the role of talking, may produce their high NTA levels.

Pucel and Stocker (1982) reported that while children in Japan are allowed to vocalize freely until well into their elementary school years, at some point, children are forced to assume "control" of themselves, at least in semi-formal settings. As a consequence, since Japanese children tend to not have a wealth of experience in semiformal settings, adult Japanese tend to be relatively poor speakers in such settings. Also, they reported that in Japan's higher education system, rhetoric is not a part of the curriculum at any level in the system. This Japanese educational environment is symptomatic of a general cultural non-emphasis on speaking in such situations, and 
does little to foster people's communication skills in semi-formal settings.

Yamamoto's study (1991) supports the assertion that Japanese adults may lack oral communication experience in whole class and group settings, at least regarding the subjects' self-perception. Upon investigating reasons for Japanese ESL students' modest participation levels in such settings, she found that the subjects said that they lacked experience in those settings and that "they had rarely been expected to say anything as an individual in public" (p.106). Moreover "because of [a] lack of such experience, they said that they could not shape their opinions quickly in a group discussion" (p.106). Yamamoto's study looked at the subjects' oral communication behavior in English speaking contexts; however, it is reasonable to assume that transfer of their home culture's communication patterns plays a role in the phenomenon.

In summation, the findings of the present study provide added support for the view that the subjects' NTA and FLA levels are significantly correlated and their NTA levels may play an important role in affecting anxiety levels when they are speaking in the second language. Additionally, previous studies indicate that Japanese 
people tend to be more highly apprehensive about oral communication, in comparison to other nationals, even when using Japanese, because Japan's culture downplays the role of speaking which causes and is caused by a lack of speaking experience. Therefore, it is suggested that having a better understanding of the Japanese subjects' high NTA levels would provide insights for understanding the nature of their FLA source.

\section{Research Question and Hypothesis 2}

Q2: What is the relation between the subjects' oral FLA levels and the subjects' self-perceived oral proficiency levels in English?

H2: There will be a significant negative correlation between the subjects' levels of oral FLA (as measured by the PRCA-Short Form), and the subjects' self-perceived oral proficiency levels in English [as measured by asking the subject's to rate their oral proficiency levels from 1 (poor) to 5 (fluent)].

There was a significant moderate negative correlation (rho $=-.45 ; \mathrm{p}<.01)$ between the subjects' oral FLA levels and their self-perceived oral proficiency levels in English. As hypothesis 2 predicts, the results showed that the subjects who perceived their oral proficiency levels in English to be lower, tended to experience higher levels of anxiety when speaking English than those who 
perceived their oral English proficiency levels to be higher.

These results are consistent with previous research findings which found a significant negative correlation between the two variables (McCroskey et al., 1895a; Elbanna, 1989).

These results are in line with common sense. That is, both hold that if individuals feel that they lack some ability for performing some given act, then in performing, or thinking about performing that act, they will feel unconfident about it; hence, they will be apprehensive in performing or, possibly, thinking about performing the act; in contrast, people who are confident about their possessing some ability to perform a given task would not be anxious in performing or thinking about performing the act.

It should be noted that as this study treats the subjects' proficiency levels as a possible "source" of FLA, there is an implication that the proficiency levels can have a causal effect on their FLA levels. However, it is not my intention to posit that there is a simple one way cause/effect relationship. Indeed, I conceptualize FLA levels and proficiency levels as being locked in a vicious circle. Learners with a low language 
proficiency level are vulnerable to being anxious when speaking the target language, and high FLA levels leads to target language avoidance behaviors, which in turn hinders improvement in the learner's proficiency. Therefore, these variables arespeculated to be involved in a mutual causality.

\section{Research Ouestion and Hypothesis 3}

Q3: What is the relation between the subjects' levels of oral FLA and the gapsize between the subjects' selfperceived oral proficiency levels in English and the subjects' self-expected oral proficiency levels in English?

H3: There will a significant negative correlation between the subjects' oral FLA levels (as measured by the PRCAShort Form) and their gapsize [as measured by asking the subjects to rate their gapsize between their selfperceived oral proficiency levels in English and selfexpected oral proficiency levels in English from 1 (a minimal difference) to 5 (a very large difference)].

There was a significant low negative correlation (rho $=-.33 ; \mathrm{p}<.01$ ) between the subjects' oral FLA levels and the gapsize between their self-perceived proficiency levels and their self-expected proficiency levels in English. These findings support hypothesis 3. Intuitively, people who were more critical about their oral English skills, because their expectations exceed their self-perceived reality, were likely to feel more anxious about speaking than were people who perceived a 
positive gap, who, it is assumed, had some self-confidence in speaking the language, because their self-perceived reality overtakes their expectation.

As described in chapter 1 , the construct of "the gapsize" was introduced in order to elaborate and better reflect on the relationship between people's FLA levels and their self-perceived proficiency levels, examined in research question and hypothesis 2. Thus, the "gapsize" variable was expected to have a stronger correlation with the FLA variable than was the proficiency variable. The initial assumption was that it is not necessarily true that people who perceive their proficiency level in the target language to be low experience high FLA levels, but rather, when people's self-perceived proficiency levels are lower than their self-expected proficiency levels, anxiety is produced. This attention to the interplay between the self-expected and self-perceived proficiency levels was assumed to be needed in order to better reflect the relation between FLA and proficiency in the target language.

However, the correlation observed between the subjects' oral FLA levels and the gapsize was not as strong as the correlation between the subjects' oral FLA levels and their proficiency levels. To my knowledge, 
there is no literature from which I could elaborate a discussion of the relationship.

To gain insight into this problem, a reexamination of the data from a new perspective was performed. This time a comparison between the means of the subjects' FLA levels among three different categories was completed. The categories were: 1) those who perceived a negative gap; 2) those who perceived no gap; and 3) those who perceived a positive gap. (It should be noted that there was in fact a fourth group of subjects who responded that they "don't know" of the existence of any gap. However, it was difficult to analyze this fourth population with the information available up to this point; thus, the between group comparison analysis was limited to the three groups)

First, the Kruskal-Wallis test (i.e., a nonparametric test for between group comparisons with more than two groups involved) was used to examine whether the three aforementioned groups exhibited significantly different oral FLA levels. However, this test, within the present SPSS's capacity (the 6.1 system), cannot specify which group's mean differs significantly from other group(s). That is, there is no comparable "multiple comparison test" 
such as the Scheffe test which is a possible add on to the one-way ANOVA for the Kruskal-Wallis test.

Thus, the Mann-Whitney test, which examines "between group mean comparison between two groups", was used to examine the group mean difference of two groups. A stricter alpha level (i.e., $\mathrm{p}<.008$ instead of $\mathrm{p}<.05$ ) was used for the adaptation of the test in order to determine which group's mean differs from other group(s). The adaptation of the Mann-Whitney test with a stricter alpha level was done on the strength of the advise from Nichols, a senior statistician at the SPSS Inc. (personal correspondence).

It was found that the negative gap group's FLA mean was significantly higher than the "no gap" group and the "positive gap" group, while no significant difference was observed between the means of the "no gap" and "positive gap" groups $(p<.008)$. These findings suggest a somewhat different relationship between the gapsize and the FLA levels, than that was previously proposed.

To review the original relationship between the gap and FLA, it was supposed that people in the three groups would experience a different degree of FLA. The group with the positive gap would report the lowest FLA levels since they think that they can speak English better than 
they should/could have and so they become confident in their ability to use English. In contrast, the people with the negative gap would experience feelings of dissatisfaction, frustration and the like, as they presumably think that they speak worse than they should/could be able to. Hence, they would experience the highest levels of FLA. People who perceived "no gap" would tend to experience middle levels of FLA as they are neither excelling nor failing.

Upon receiving the test results, it became clear that the initial conceptualization needed some modifications. One possible interpretation of the results is that only the subjects' negative gap is connected to their FLA levels, and that as soon as their expectation level meets the threshold of their selfperceived "reality", then the existence or the nonexistence of the gap becomes unconnected to their FLA levels.

\section{$\underline{\text { Research ouestion } 4}$}

Q4: Which possible source among the three proposed has the strongest correlation with the subjects' oral FLA levels?

Table $V$ summarizes the correlation between each of 
the three proposed sources and the subjects' oral FLA levels. The results show that the NTA variable and the proficiency variable exhibited a similar moderate strength of correlation with the FLA levels, while the gapsize variable was found to be modestly correlated with the FLA levels.

TABLE V

CORRELATION BETWEEN EACH OF THE THREE PROPOSED SOURCES AND FLA LEVEL*

FLA LeVe1

NTA Level .46

S-P P Level.

$-.45$

Gapsize

$-.33$

*All correlations are significant, $\mathrm{p}<.01$

- Self-Perceived Proficiency level

The conclusions to be drawn from these findings are that the subjects' traitlike characteristic to be anxious in any given communication-bound situation and their English proficiency levels are equally strong candidates of influencing the subjects' FLA levels.

The conclusions reached in this study reject the generalization made by McCroskey et al.'s study which 
found that the NTA variable was twice as good a predictor of the FLA levels than was the proficiency variable, and then concluded by suggesting that FLA should be conceptualized as "a broad trait-like predisposition".

The differences found between this study and McCroskey et al.'s study may be explained by the different language learning environments of the subjects in each study, as I speculated in chapter 1 . More specifically, I think that the differences found were due to the fact that the subjects in each study attached differing degrees of importance to reaching some given level of proficiency in the target language.

Although this idea may be too "fuzzy" to be of much help, if one makes distinction between A) ESL versus B) NON-ESL environment (i.e., A. ESL environment: learners live in their target language environment; B. NON-ESL environment: learners live in their native language environment), the merits of this point become more clear. Generally speaking, people in an ESL environment perceive learning the target language to be more important than people in EFL environments do, because in the ESL environment, the target language is a necessary survival tool both inside of their home institutions and outside. 
If people find speaking the language to be necessary and important, then obviously, whether doing it well or not will be an issue for them. Positing that the assumption is true, it is logical to view the relationship between people's proficiency levels and their FLA levels as being strongly related. On the other hand, if a given population assigns only secondary importance to learning the target language, then being a proficient speaker should not be particularly important to them; hence, the relationship between FLA and proficiency should not be a strong one.

With the above 'importance factor' borne in mind, the differences found in the two studies are reasonably explained. This study focused on Japanese students in American institutions, where the day to day language was English (i.e., ESL context). Because their skill in using English was of critical importance to how well they succeeded both academically and socially, their proficiency levels in English were correlated almost as strongly with their FLA levels as with their NTA levels.

The Puerto Rican subjects in McCroskey et al.'s study were from a bilingual country, where Spanish is far more common than English is. Due to the fact that English was not the day to day language of McCroskey et 
al.'s Puerto Rican subjects, they likely placed a comparatively light degree of importance on being able to speak English well. This relative unimportance that they attached to using English explains why they exhibited a much weaker correlation level between their FLA levels and their proficiency levels than the correlation between their FLA levels and their NTA levels, as opposed to the Japanese students in the U.S. who participated in my study .

In sum, the findings in this study, compared with McCroskey et al's study, seem to suggest that the source of FLA should be viewed as varying according to the language learning environments in which the actors find themselves, since the degree of importance attached to speaking the target language proficiently, differs from person to person in different language learning environments.

In the above data analyses, for each subject there was only one score for the FLA variable, which was obtained by collapsing together ten different scores which represented the subjects' anxiety levels in ten different communication contexts. As a result, the combined score does not reflect the subjects' different FLA levels in different communication contexts. 
However, in this section, the ten scores for the FLA variable were examined individually, in order to see whether a correlation existed between each of the three proposed FLA sources and the subjects' FLA levels in a particular communication context. More exactly, a correlational analysis (i.e., Spearman's rho test) was performed between 1) each of the ten scores in the FLA variable and each of the ten scores in the NTA variable; 2) each of the ten scores in the FLA variable and the self-perceived proficiency variable; and 3 ) each of the ten scores in the FLA variable and the gapsize variable.

Table VI presents 1) correlations between the ten scores of the FLA variable and the ten from the NTA variable. The numbers in the table correspond to the numbers in the questionnaire (see appendix B): question 1 inquired about the subjects anxiety levels in a classroom setting (20 people); questions 2 and 7 were concerned with group discussion settings (4-5 people); questions 3,4 and 5 were about public speaking; question 6 was about conversations with a classmate; question 9 regarded conversations with people; question 10 was about presenting a speech on a local television show; and in question 8 , no situation was specified, but rather the 
subjects were asked whether they are comfortable using their body and voice expressively.

Regarding the correlations between the FLA and the NTA variables, besides question 9, all the scores had a significant relationship. There was a relatively strong correlation found in question $3($ rho $=.58 * *)$, question 10 $\left(r h o=.50^{* *}\right)$, and a moderate correlation was found in questions 4 and 5 (rho $=.41^{* *}$ and $.43 * *$ respectively), while low correlation was observed in question 6 $\left(\right.$ rho $\left.=.15^{*}\right)$ and no correlation was found in question 9. In sum, the data show that in public speaking settings (as measured in questions 3,4 and 5) and the television speech setting (as measured in question 10), relatively strong correlation levels were observed between the subjects' FLA and NTA levels. On the other hand, situations where a low or no correlations were found were those that dealt with talking with a person or people (as measured in questions 6 and 9). 
TABLE VI

CORRELATIONS BETWEEN THE FLA VARIABLE AND THE NTA VARIABLE

\begin{tabular}{|c|c|c|c|c|c|c|c|c|c|c|}
\hline & 1 & 2 & 3 & 4 & 5 & 6 & 7 & 8 & 9 & 10 \\
\hline 1 & $.38^{* *}$ & $.16^{*}$ & $.29^{\star \star}$ & $.16^{*}$ & $.23^{* \star}$ & $.21^{\star \star}$ & $.22^{\star \star}$ & $.15^{*}$ & .11 & $.25^{\star \star}$ \\
\hline 2 & $.16^{\star}$ & $23^{* *}$ & .06 & $.16^{\star}$ & $.20^{\star *}$ & .12 & $.16^{*}$ & $.14^{*}$ & $.20^{\star \star}$ & .06 \\
\hline 3 & $.30^{* *}$ & .09 & $58^{\star \star}$ & $.24^{\star \star}$ & $.29^{\star *}$ & .12 & $.28^{\star \star}$ & .10 & .09 & $.45^{\star \star}$ \\
\hline 4 & $.27^{\star \star}$ & $.17^{*}$ & $.35^{\star *}$ & $.41^{* *}$ & $.34^{* *}$ & $.19^{* \star}$ & $.20^{\star \star}$ & .11 & .09 & $.31^{\star \star}$ \\
\hline 5 & .09 & .04 & $.22^{\star *}$ & $.23^{* *}$ & $.43^{* *}$ & .10 & .05 & .09 & .06 & $.23^{\star \star}$ \\
\hline 6 & $.15^{\star}$ & .08 & $.22^{\star \star}$ & .05 & .05 & $.15^{\circ}$ & $.16^{\star}$ & .01 & .01 & .10 \\
\hline 7 & $.20^{\star *}$ & $.18^{\star \star}$ & $.22^{\star \star}$ & .08 & $.15^{\star}$ & $.18^{\star *}$ & $.37^{\star \star}$ & $.14^{*}$ & $.22^{\star \star}$ & .12 \\
\hline 8 & .07 & $.15^{\star}$ & .10 & .11 & $.16^{*}$ & .02 & .07 & $.39^{* *}$ & $.20^{\star \star}$ & .01 \\
\hline 9 & .04 & .06 & .03 & -.02 & .05 & .04 & -.01 & .05 & .13 & .01 \\
\hline 10 & $.26^{\star \star}$ & .12 & $.38^{* *}$ & $.15^{\star}$ & $.29^{\star \star}$ & $.21^{* *}$ & $.18^{\star *}$ & .05 & .02 & $.50^{* *}$ \\
\hline
\end{tabular}

*-Signif. LE $.05 \quad * *$ - Signif. LE .01 (2-tailed)

NOTE: Individual items in both the FLA and the NTA variables range from 0 to 1 . 
Table VII presents correlations found between the ten scores of the FLA variable and the self-perceived proficiency variable. The numbers of the FLA variable in the table correspond to the question numbers in the questionnaire.

For this correlational analysis, a correlation in any of the ten different contexts was found to be significant at either a .05 or .01 level. Especially the strong correlation was found in the "conversing with people" situation measured in question $6\left(\right.$ rho $\left.=-.68^{* *}\right)$, as opposed to the low correlation which was found in the public speaking setting (as measured in question 3 ) and the TV speech situation (as measured in question 10; rho= $-.15^{*}$ and $-.17 *$ respectively).

TABLE VII

CORRELATIONS BETWEEN THE FLA (F) AND THE SELF-PERCEIVED PROFICIENCY (S-P P) VARIABLES

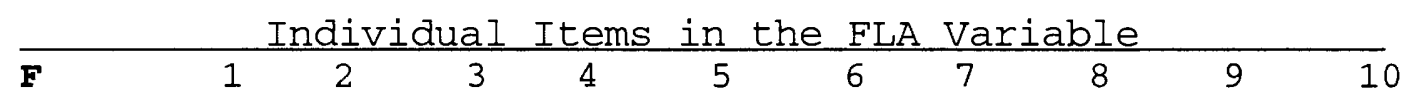

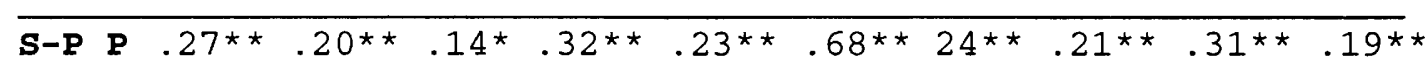

*-Signif. LE .05 **-Signif. LE .01 (2-tailed)

- All the correlations are negative.

NOTE: Individual items in the FLA variable and the S-P variable range from 0 to 1 . 
Table VIII presents correlations observed between ten scores from the FLA variable and the gapsize variable. The numbers of the FLA variable in the table correspond to the question numbers in the questionnaire.

In this correlational analysis no correlation was seen in questions 2,8 and 10, and a modest correlation (the rhos ranged from $-.37^{\star *}$ to $-.27^{* *}$ ) was observed in a variety of situations, such as "conversing with a person or people" (questions 6 and 9), "speaking on a platform" (question 4), "participating in a group discussion" (question 7) and "speaking in a class" (question 1). Because of the similar levels of correlations found in a variety of communication settings, any situational pattern is difficult to see from this analysis.

TABLE VIII

CORRELATIONS BETWEEN THE FLA (F) AND THE GAPSIZE (G) VARIABLES

\begin{tabular}{|c|c|c|c|c|c|c|c|c|c|c|}
\hline $\boldsymbol{F}$ & 1 & 2 & 3 & 4 & 5 & 6 & 7 & 8 & 9 & 710 \\
\hline & & .10 & • & * & 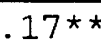 & $7 \times n$ & $20^{\wedge} \mathrm{n}$ & 08 & 20 & .12 \\
\hline
\end{tabular}

*-Signif. LE .05 **-Signif. LE .01 (2-tailed)

- All the correlations are negative. NOTE: Individual items in both the FLA and the Gapsize variables range from 0 to 1. 
The following three tables (IX, $\mathrm{X}$ and $\mathrm{XI}$ ) categorize the strength of correlations found in the above three correlational analyses, along a continuum of communication formality, in order to illustrate the patterns.

The patterns in table IX show that in

public speaking situations and a TV speech situation, the FLA and NTA levels were relatively strongly correlated, while in conversational settings, the correlation was either notably weaker, or was not observed.

TABLE IX

CORRELATIONS BETWEEN THE FLA AND THE NTA VARIABLES

CATEGORIZED ALONG A CONTINUUM OF COMMUNICATION FORMALITY

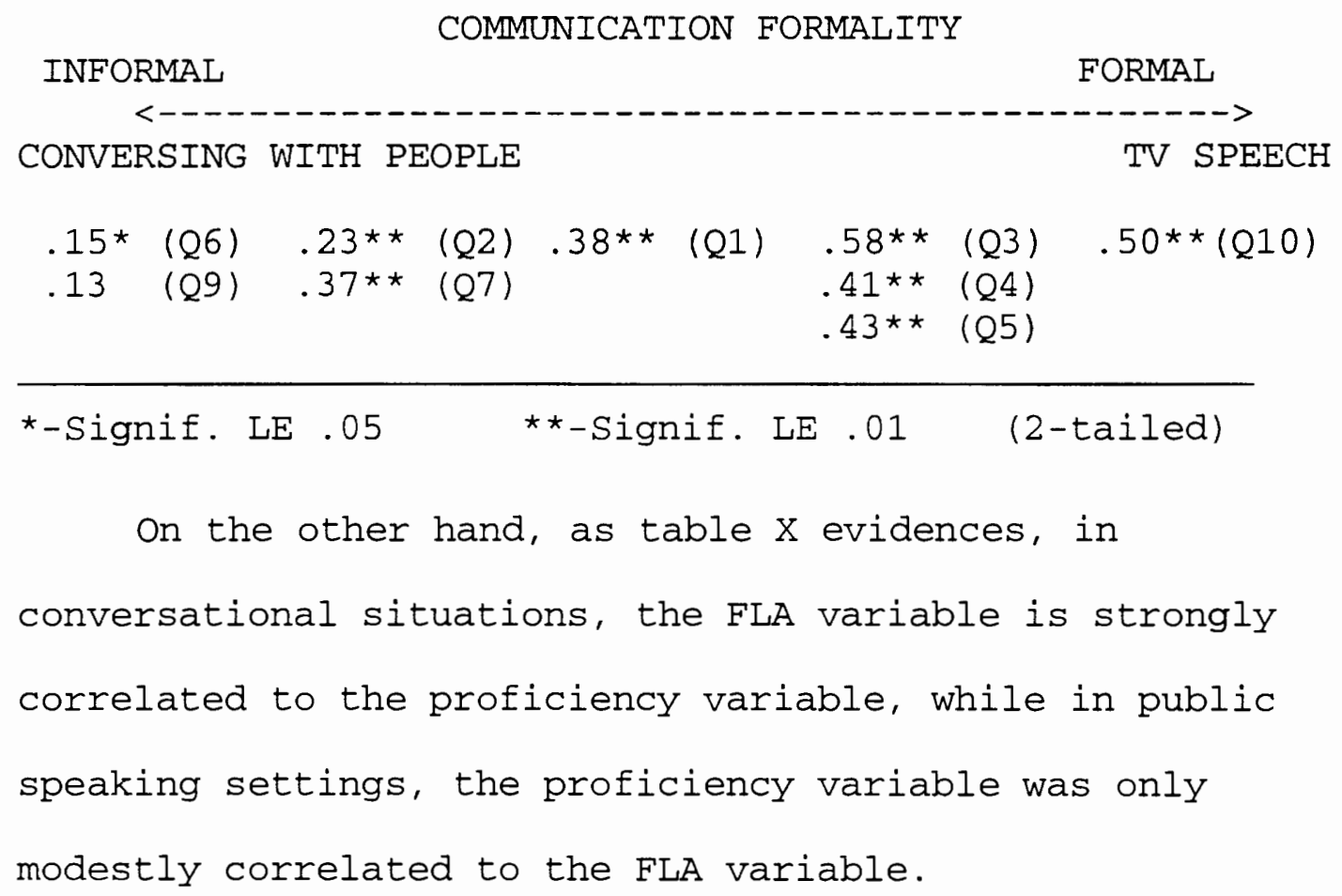


TABLE X

CORRELATIONS BETWEEN THE FLA AND THE SELF-PERCEIVED PROFICIENCY VARIABLES ALONG A CONTINUUM OF COMMUNICATION FORMALITY

COMMUNICATION FORMALITY

INFORMAL

FORMAL

CONVERSING WITH PEOPLE

TV SPEECH

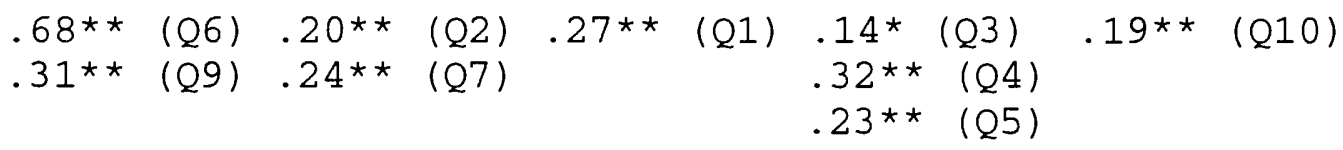

*-Signif. LE .05 **-Signif. LE .01 (2-tailed)

- All the correlations are negative.

Table XI shows that similar strengths of

correlations were observed all over the continuum of communication formality; thus, it is difficult to see any particular pattern.

TABLE XI

CORRELATIONS BETWEEN THE FLA AND THE GAPSIZE VARIABLES

ALONG A CONTINUUM OF COMMUNICATION FORMALITY

COMMUNICATION FORMALITY

INFORMAL

FORMAL

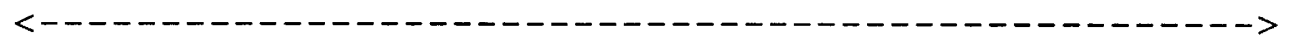

CONVERSING WITH PEOPLE

TV SPEECH

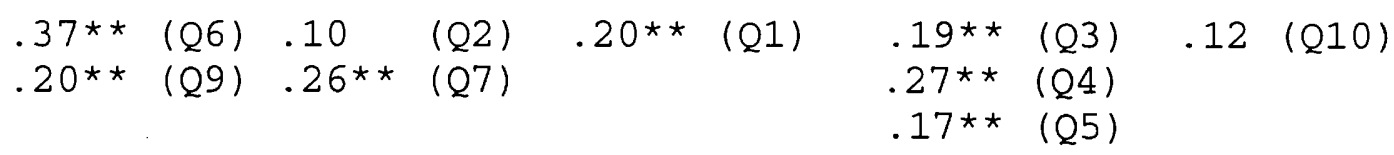

*-Signif. LE .05 **-Signif. LE .01 (2-tailed)

- All the correlations are negative. 
The patterns that emerged in the above analysis suggest that FLA may have different sources in different situations. More exactly, in rather formal settings, such as delivering a public speech or presenting a speech on a TV show, the subjects' NTA levels may largely affect their FLA levels, while in more informal settings, such as "conversing with people", the subjects' proficiency levels may largely influence their FLA levels.

The above analyses are correlational studies, which only demonstrate the strength of relation between variables, and do not specify the directionality of the cause/effect relationship. Nevertheless, it is logical to assume that the arrow of causality emerges from the NTA variable and points to the FLA variable. Were it the other way around, then the following would make sense: "I was a nervous 7 year old BECAUSE when I was 24, my foreign language class scared me".

Furthermore, I conceptualize the relationship between self-perceived proficiency levels and FLA levels as being locked in a vicious circle, as discussed above. For example, learners with a low language proficiency level are vulnerable to being anxious when speaking the target language, and those with high FLA levels tend to 
choose avoidance behaviors, which in turn retard improvement in their proficiency.

In sum, it seems to be appropriate to conceptualize that FLA is a complicated variable with two main sources: 1) NTA levels set an individual's base line of apprehensiveness in formal settings, and this baseline setting is reflected in their FLA levels (NTA $\rightarrow$ FLA);

2) proficiency levels both affect and are affected by FLA levels (proficiency $(->$ FLA) in informal settings.

\section{Research Question 5}

Q 5: Do the subjects' demographic factors, such as their age, gender, status at school and the length of residence in English speaking places affect the subjects' oral FLA levels?

Combined with the demographic information gathered from the survey, it was examined whether the subjects' age, gender, status in school, or years of residence in English speaking places affected the subjects' FLA levels. However, it should be noted that the discussion regarding the statistical results for the interaction between these variables and the subjects' FLA levels will be limited, because the issues were not a central concern of this study and there are not many studies available which address the interaction between the above biographic factors and peoples' FLA levels. Rather, that 
information is included here only with a hope that it may be of help to some future researchers.

Age

Table XII displays the FLA mean levels of each age group (18-23, 24-29\&30+); the younger the subject groupings, the higher they reported their FLA levels to be. However, as can be seen in the table, the age difference was not statistically significant in affecting the subjects' FLA levels.

TABLE XII

GROUP MEAN DIFFERENCE AMONG DIFFERENT AGE GROUPS

\begin{tabular}{|c|c|c|c|}
\hline Age & & Mean Rank & Cases \\
\hline $18-23$ & & 121.75 & 155 \\
\hline $24-29$ & & 111.04 & 50 \\
\hline 30 or More & & 96.46 & 27 \\
\hline & D.F. & $\begin{array}{l}\text { Significance } \\
.1583\end{array}$ & \\
\hline
\end{tabular}

In previous research a distinction has been drawn between children and adult learners' FLA levels (Twyford, 1987; Kulick, 1990) and adults are generally found (and assumed) to be more prone to experience higher FLA than their young counterparts tend to. However, little 
research has been directed at studying how adults' age affects their FLA levels.

\section{Gender}

Table XIII represents the means of the FLA levels of the two genders. The means were very close and were far from being statistically significant.

TABLE XIII

GROUP MEAN DIFFERENCE AMONG DIFFERENT GENDER

$\begin{array}{lcc}\text { Gender } & \text { Mean Rank } & \text { Cases } \\ \text { Female } & 116.08 & 150 \\ \text { Male } & 117.27 & 82\end{array}$

2-Tailed $\mathrm{P}$ .8974

This result supports Philips' study (1989) and contradicts El-banna's findings. El-banna is a researcher based in Egypt, who argued in a 1989 study that a gender difference in FLA levels exists, and is due to "gender roles". One example of the power of "gender roles" is easily seen in the gender disparity of success in the field of Mathematics. This explanation implies that in order to see gender differences in FLA levels clearly, one must also see the cultural prescriptions that determine the 
"perceived superiority" of the language learning ability of one gender over the other.

\section{Status in School}

Table XIV shows the means of FLA levels of people who belong in one of the following six categories: 1) ESL only, 2) ESL + regular, 3) exchange program, 4) undergraduate, 5) graduate and 6) others. No statistically significant differences were observed. Also, no references to previous studies were found, regarding the subjects' FLA levels and their status in school.

TABLE XIV

GROUP MEAN DIFFERENCE AMONG THE SUBJECTS WITH A DIFFERENT STATUS IN SCHOOL

\begin{tabular}{|c|c|c|}
\hline Status & Mean Rank & Cases \\
\hline ESL Only & 135.16 & 61 \\
\hline ESL + Regular & 99.92 & 12 \\
\hline Exchange Program & 99.96 & 41 \\
\hline Undergraduate & 116.07 & 89 \\
\hline Graduate & 98.95 & 19 \\
\hline \multirow[t]{3}{*}{ Other } & 115.89 & 9 \\
\hline & Significance & \\
\hline & .0973 & \\
\hline
\end{tabular}

Year(s) of Residence in English Speaking Places

Table XV shows the FLA means of the subjects who had 
been living in English speaking places for one of four varying lengths of time: 1) less than one year, 2) one to three years, 3) four to seven years, and 4) eight or more years. The number of years that a person had been living in English speaking places was found to have no statistically significant effect on the subjects' oral FLA levels. These findings are in concord with Allen and Andriate's work (1984b).

TABLE XV GROUP MEAN DIFFERENCE AMONG THE SUBJECTS WHOSE RESIDENCE OF YEAR(S) DIFFERS

\begin{tabular}{lcr} 
Year $(\mathrm{S})$ of Residence & Mean Rank & Cases \\
\hline Less Than 1 YR & 118.77 & 105 \\
$1-3$ YR & 120.07 & 57 \\
$4-7$ YR & 115.90 & 58 \\
8 or More & 82.58 & 12
\end{tabular}

D.F.

3
Significance

.3407

\section{summary}

This chapter provided the descriptive statistics for the four variables used in the statistical analysis and reported the results of the statistical analysis of the 
121

research questions and hypotheses. Also, a discussion of the results with reference to previous studies was given. 


\section{CHAPTER 5}

\section{CONCLUSION}

\section{Introduction}

This chapter presents the conclusion of this research, offers some suggestions for the TESOL profession, and discusses some of the limitations of this research while providing some suggestions for future SLA researchers.

\section{Conclusion}

This study attempted to locate some possible sources of oral FLA among Japanese students in the U.S. through the use of a questionnaire. Three possible sources were proposed: 1) the subjects' traitlike tendency to be anxious in any given communication-bound context; 2 ) their self-perceived oral English proficiency levels; and 3) the gapsize between their self-perceived oral English proficiency levels and their self-expected oral English proficiency levels. Correlational analyses were performed in order to examine whether a significant relationship was observed between each of the proposed 
FLA sources with the subjects' FLA levels, and if so, which source had the strongest correlation with the FLA levels.

First, a significant moderate positive correlation was observed between the subjects' oral FLA levels and oral NTA levels $(.46 ; \mathrm{p}<.01)$. It may be interpreted that these results show that the subjects' tendency to be apprehensive in any given communication-bound context is a source of their FLA.

Second, a significant moderate negative correlation between the subjects' self-perceived proficiency levels and their oral FLA levels was observed $(-.45 ; \mathrm{p}<.01)$, which seems to suggest that their self-perceived proficiency levels in English may affect their FLA levels.

Third, a significant modest negative correlation between their gapsize and their oral FLA levels was found $(-.33 ; \mathrm{p}<.01)$, which supports the view that the subject's FLA levels may be influenced by the gap between their self-perceived proficiency levels and their self-expected proficiency levels.

Additional data analysis showed that people who perceived a negative gap reported significantly higher FLA levels than those who categorized themselves as 
belonging to either the "positive gap" or "no gap" group, while no difference was found between the FLA levels reported by the "no gap" or the "positive gap" groups. These results may imply that the negative gap is a FLA source; however, as long as the expectation levels meet the self-perceived proficiency levels, existence of either "positive" or "no gap" is unrelated to the subjects' FLA levels.

This study argues that McCroskey et al.'s (1985a) conclusion which suggested that FLA should be conceptualized as a broad traitlike predisposition is an overgeneralization, because in this study, both the NTA and the self-perceived English proficiency variables were found to have almost equal strength of correlation with the FLA levels; hence, each are equally strong candidates for being the subjects' FLA source. Taken together, their study and this study, show that it would be more accurate to view the FLA source as varying for people in different language learning situations, because people in different environments attach differing degrees of importance to learning the target language.

Additional data analysis, with a more situation sensitive methodology, shows that in public speaking 
situations the subjects' FLA and NTA levels had moderate correlations, while in situations that involved conversing with other people, only low or no correlations were observed. Between the FLA and English proficiency variables, a strong correlation was found in the "conversing with people" situation, while a low correlation was found in public speaking situations.

To summarize, these results lend one to suspect that FLA, depending, to a large degree, on situation, springs from different sources. That is, some subjects were simply apprehensive about speaking in formal settings, such as delivering public speeches or presenting a speech on a TV show, regardless of language; hence, they possess a traitlike tendency to be apprehensive in those settings. On the other hand, in more informal settings, such as, "conversing with people", the subjects' selfperceived proficiency levels in English may strongly affect their FLA levels. Hence, it seems reasonable to argue that the subjects' FLA, in different situations, comes from different sources.

While this study attempted to locate some possible sources of FLA, it must be noted that correlational analyses, which this study depended on, only demonstrate the strength of the relationship between variables, and 
say nothing about the directionality of the cause/effect relationship between the variables. However, logical explanations were offered as to the directionality of the relationship.

Lastly, the subjects' biographical factors (age, gender, status at school and year(s) of residence in English speaking places) did not have a statistically significant effect on their oral FLA levels.

\section{Implications for Teaching}

While this study's purpose was to examine the interplay between anxiety and the subjects' language learning, it can offer some suggestions for pedagogical purposes. It should be noted that while in the literature some researchers use the concept of "facilitative anxiety", in this study FLA is understood as having a negative effect on people's language learning. Thus, lowering the students' FLA levels becomes important, particuraly for language educators who have Japanese students who are preparing for higher/professional education in the U.S.

All three of the proposed sources of FLA had a significant relationship with the FLA variable. These findings suggest that helping students to 1) lower their 
NTA levels; 2) increase their self-perceived oral proficiency levels in English; and 3) minimize the negative gap between the subjects' self-expected proficiency levels and their self-perceived proficiency levels (if a gap does exist in the subject in question), are all likely to reduce the subjects' FLA levels.

Some practical suggestions to deal with the above three issues are provided for language educators in the next part of this chapter; NTA reduction and proficiency level increase are emphasized, since they had a stronger correlation with the FLA variable.

\section{1) Lowering Students' NTA Levels}

The subjects' NTA levels seem to play an important role in affecting their FLA levels, and particularly the influence seems most powerful in formal settings, such as giving public speeches.

For beginning learners, teachers may, together with the students, select some good stories, songs or poems to be read aloud, sung or performed by the students in front of an audience of their peers. Students will learn to perform the task in a smooth manner, all the while paying attention to controlling their voice volume, body movements, and expressions. It should be noted that these types of activities are not primarily 
intended to focus on improving the students' English skills per se, rather, they are designed to improve their presentation skills. Improved presentation skills should lower the students' communication-bound anxiety levels, which are related to NTA levels; hence, their FLA levels.

For advanced learners, teachers may have them produce and present their own work, since they will face a similar task sooner rather than later once they enter their regular university/professional classes. It seems like an especially good idea for the teacher to assign the task of public speaking on a topic which the students themselves research. This will have the benefit of having the students produce a paper and presentation which they are interested in and presumably informed and animated about. Also, the handling of the supplemental materials, such as making handouts or using overhead projectors will be learned. This type of experience should decrease the advanced students' communicationbound anxiety levels, which are related to their NTA levels; hence, it should lower their FLA levels. 
2) Increasing Students' Self-Perceived Proficiency Levels in English

A discussion of how to increase the students' proficiency levels in English is far beyond scope of this section, but rather the issue of increasing the self-perception of proficiency levels will be briefly addressed. The self-perceived proficiency levels and the FLA variable exhibited a particularly strong relationship in informal settings, such as conversing with people; thus, it is speculated that an increase in the selfperceived proficiency levels would effectively reduce the subjects' FLA levels in informal settings.

One way of helping students to increase their selfperceived proficiency levels is to change their attribution pattern when communication breakdowns occur. It is my impression that when communication breakdowns happen in the target language, most learners tend to blame themselves (e.g., their accented pronunciation). However, it can and should be profitably pointed out to the learners that listening as well as speaking is not a passive activity. Listeners actively choose to pay attention or not. Listeners, generally speaking, do have it within their capability to understand "accented" English, if they put their mind to it. That is, it is 
often the listener's choice whether or not to bother to understand the speaker (whether native or learner). Once the active role of listening has been pointed out to the learners, then, in future, when there is a communication breakdown the learners can analyze the situation and avoid attributing the cause of failure completely unto themselves. Getting the students who internalize all faults to change their attribution patterns should heighten their self-perceived proficiency levels.

Second, teachers can help students to increase their self-perceived proficiency levels by reminding students that communication is not always smooth even when people speak in their native tongue. While this is common sense, when learners speak in their target language, many of them become hypersensitive to nonsmooth features of communication, and regard them as mistakes made by language learners. These hypersensitive students often wish to obtain the unobtainable and achieve "perfectly smooth English communication" in which all words flow naturally to the speakers' mind, are pronounced perfectly, in a situation appropriate manner, and hopefully are even witty. If teachers remind the students that real language usage is filled with hiccups, glitches and snags, the students may not be so 
critical of themselves and their self-perceived proficiency levels should rise.

Furthermore, teachers can help students to experience "successes in communication" by having them accomplish some simple tasks in real life situations. This is an issue because beginning students, generally speaking, are in the unenviable position of being at the beginning of a long, arduous, painful and boring task, wherein they are consistently being corrected and are rarely afforded any rewards, beyond good grades.

Therefore, in an effort to get the students to experience some successes in their language learning endeavor so that their self-perceived proficiency levels will rise, the teachers should assign difficult, but manegeable tasks, outside of academia, wherein the students must use English. For example, a student could be assigned to go across town, to some given market, buy something and bring back the receipt as proof. In performing this task the student most likely must read bus schedules, ask directions and return; simple, yet difficult and memorable. The successes of performing these types of tasks will give the students a taste of success which will in turn, heighten their selfperceived proficiency levels. 
3) Minimizing the Negative Gap between the Subjects' Self-Expected Proficiency Levels and their Self-Perceived Proficiency Levels

To minimize the negative gap, either the selfperceived proficiency levels can be increased or the self-expected levels can be lowered. This section offers suggestions on how to dispel students' unrealistic beliefs about foreign language learning which lead to their overly high expectations.

"The Myths and the Realities of Foreign Language Learning" (Campbell \& Ortiz, 1991) is a short, fun multiple choice quiz which pokes fun at and educates about some common myths that people hold about language and language learning. This quiz asks questions like: in a percentage form, how important is general intelligence to successful language learning? To what percent does musical ability account for successful language learning? Does successful learning a foreign language require a special talent which only a few people have? While the intended audience of this quiz is English-speaking people who are learning a foreign language, it is applicable for Japanese students, with only a minimum amount of modification.

This quiz, or something like it, could be used in a class or group discussion to examine common myths and 
the realities of language learning. These exercises should help students to develop a more realistic view about language learning, which in turn should lower their high expectations which in turn, should minimize their negative gap.

\section{Limitations of the study and Suggestions for Future SLA Researchers}

The limitations of this study, while offering a few suggestions for future researchers will be discussed in the following section, which is divided into two parts:

1) limitations of survey research in a general sense; and

2) limitations of this research effort (i.e., the constructs and the questionnaire used in this research effort).

\section{Limitations of Survey Research in General}

First of all, as this research effort relied

entirely on a questionnaire to gather data, its scope is limited. While not a part of the original research design, I had several informal talks (mostly about the gapsize construct) with some of the participants, which turned out to be highly informative. Through these extra interviews I realized the power of the interviews, and I recommend to future researchers to incorporate them in their research methodology. 
Secondly, while this study seeks possible sources of FLA, it utilized a small, nonrandomly selected, population of Japanese students in Oregon ( $\mathrm{N}=232)$; therefore, one must generalize from these findings with caution.

Finally, the ethnicity of the researcher may have influenced the subjects' responses through "ethnic affirmation", which is a descriptive term applied when subjects shift behavior towards what they believe to be ethnically appropriate (Bond \& Cheung, 1984). While this is an inescapable problem as both the language of the survey and the cover letter itself provide the subjects ample data from which to draw the conclusions about the ethnicity of the researcher, the influence of the ethnicity of the researcher on the subjects' responses must be borne in mind.

Problems of the Constructs and the ouestionnaire in this study

In the process of designing this research through a review of the literature, consultation with professionals and a pilot study, every attempt was made to ground the constructs of FLA, NTA, self-perceived proficiency and the gapsize and to create a valid and reliable questionnaire; nevertheless, unanticipated issues were 
brought to light after the data collection procures had been begun. The following will discuss these issues in relation to each construct, with some of the comments made by the subjects being incorporated.

\section{FLA and NTA Constructs (the PRCA-Short Form)}

First, MCCroskey (1990) warns that the PRCA-Short Form can only be applied to foreigners with caution, because the form was designed for Americans. Herein, the question "I dislike using my body and voice expressively" is of dubious applicability to the Japanese subjects examined in this research, as the underlying assumption of that question is that comfortable speakers use their voice and body expressively. This assumption may be at loggerheads with the Japanese cultural tendency to view what Americans would likely categorize as "dynamic" speakers as being merely fidgety. Thus, this question when applied to Japanese subjects threatens the validity of, at least one item of, the PRCA-Short Form.

Furthermore, the data collection procedure of using a single test question twice in order to measure two variables needs more consideration. In the questionnaire used in this study, the same test (PRCA-Short Form) was used to assess both the subjects' FLA and NTA levels in two separate sections. Attempts were made to 
differentiate the two sections; for example, underlined headings (e.g., The following section is concerned with Japanese speaking contexts) were used, and every single question specified whether a given question was concerned with the subjects' anxiety levels when speaking in Japanese or English. However, it is easily imaginable that some subjects' responses in either context were affected by their answers in the other language context. It might be useful to administer the PRCA for both the FLA and NTA variables in two different ways:

1) administer the language differentiated versions of the PRCA independently with some interval between them, and then, 2) administer the PRCA which has both languages included in a single questionnaire, to the subjects. Then the results from the two steps could be compared in order to see whether the subjects' FLA and NTA levels are being influenced by the data collection procedure.

Thirdly, the PRCA-Short Form questions the subjects about their anxiety levels in 1) a highly hypothetical setting and in 2) situations where they have had little speaking experience (i.e., 1) presenting a speech on a local television show and, 2) public speaking and oral participation in a whole classroom setting). 
Within English speaking contexts, the subjects may have had sufficient experience of speaking in public or speaking out in a whole class setting since they are in the American educational system, where oral participation is valued. However, in Japanese contexts it is assumed that for many Japanese subjects, such experiences would only be hypothetical or rather limited. [note: this feature of Japanese school was discussed above (Pucel \& Stocker, 1982)]. Thus, a questionnaire which asked Japanese subjects what they would do in such a situation could, for them, only be hypothetical question.

Subjects who are asked to imagine and rate what their anxiety levels would be in some given situations, which they have not yet experienced, are faced with a problem as they do not have sufficient information with which to produce an informed answer. As a consequence, their answers to those questions do not come from their anticipated anxiety levels in relation to specific situations described in the questions; rather, they are drawn from the subjects' anticipated anxiety levels about an inexperienced situation (Beatty \& Andriate, 1985).

Beatty and Andriate (1985) found that the predictivity of their subjects' anxiety levels in public speaking increased after the subjects had actually spoken 
in public, suggesting that if researchers are seeking to describe some psychological reality in their subjects, then they had best avoid hypothetical questions. The benefits provided by the highly hypothetical questions contained in the PRCA-Short Form need to be weighed against where the subjects are from and what their (likely) life experiences are.

Fourthly, in my translated PRCA-Short Form, some English lexical phrases do not translate easily into Japanese without residue. For example, the word "public" was rendered into Japanese as "ooyake no ba"; however, it possibly meant different things to different subjects. The use of the phrase, "in public" in the following question "I always avoid speaking in public as much as possible" was intended to specify a rather formal situation, such as delivering speeches in a class or a meeting. However, in a questionnaire, a subject wrote that "speaking with a friend in public is comfortable for me"; this comment shows that her interpretation of "public" (ooyake no ba) means a place shared by people, such as a cafeteria, and not necessarily a formal situation. Thus, to the extent that the original question's intent and the subject's interpretation differ, the validity of the questionnaire is threatened. 
Finally, and most importantly, PRCA-Short Form is limited by its blindness to anxiety experienced in different communication situations. Five subjects mentioned that information which was provided in the questionnaire was not sufficient to determine their responses. For instance, a subject wrote in response to the question "When I talk to a classmate one on one, I am afraid to speak up in conversations", that her answer would "vary depending on who the classmate is". Another person indicated that her responses would differ to the question "I like to get involved with group discussions", depending on whether the group was comprised of "Americans, Japanese, or others".

Although some modifications were made in order to better specify and delimit the communication contexts, to some individuals certain situations in the questions were still too vague (see the section in chapter 3 which presents modifications of the original questions in the PRCA-Short Form) . This criticism can be summarized by saying that the PRCA-Short Form is sensitive to the formality of the communication involved; nonetheless, it is not sensitive to interlocutors in the settings. This participant dynamic is of critical importance in examining communication-bound anxiety levels and needs to 
be borne in mind by researchers in their selection/development of questionnaires.

Self-Perceived Oral Proficiency Variable

Questions which measured the subjects' selfperceived proficiency levels in the questionnaire did not specify any context, but rather asked the subjects their proficiency levels in a "general" sense. The assumption behind this line of questions is that proficiency is a stable feature across, or regardless of, contexts.

However, there exists a view which holds that communication competence levels vary from contexts to contexts (McCroskey, 1985), paralleling the "situational approach to anxiety" which posits that people's anxiety levels fluctuate in different situations.

This idea of communication competence varying in different situations can be easily and profitably applied to the construct of oral proficiency which was used in this research. Such an application would be appropriate as language learners often comment that they can speak "better" or "worse" in different situations, which may or may not be true; however, it certainly reflects their perception about their oral proficiency.

Thus, in order to reflect the subjects' selfperceived oral proficiency levels more comprehensively, 
the questionnaire could have included questions which measure their proficiency levels in contexts. There is an instrument available named the Self-Perceived Communication Scale (McCroskey \& Richmond, 1987), which assesses people's self-perceived communication competence levels in various situations; the contexts in the questions are created with different kinds of interlocutor(s) as well as with different degrees of formality or different sizes of people involved. Even though this instrument was not utilized in this research effort, due to the various constraints, I recommend it to researchers who are interested in assessing people's self-perceived proficiency in the target language in order to mirror the subjects' perception more comprehensively.

The Gapsize between the Subjects' Self-Perceived Oral Proficiency Levels and Self-expected Oral Proficiency Levels in English

Since the construct of "gap" was not grounded in other research, two points have to be reconsidered. First, like the above questions which measured the subjects' self-perceived proficiency levels in the questionnaire, the gapsize question asked, without specifying any context, whether a gap existed or not, and 
if so, how large was it. The assumption behind this line of questions is that gap or gapsize is a stable feature across, or regardless of, contexts. However, the view that people's self-perceived proficiency levels may vary depending on the situation which they are in, was introduced above. This view obviously poses a problem for the gapsize construct because the gap is determined by the distance between the subjects' self-perceived and self-expected proficiency levels. If one criteria (i.e., the self-perceived proficiency levels) on which the gapsize is based is itself liquid and fluctuates in accordance to situations, then the gapsize itself is also necessarily a liquid construct that fluctuates in accordance to situations.

Secondly, it was found that the same individual may perceive both a positive and a negative gap at the same time. During the data collection period, I had an informal talk with a subject concerning the questionnaire. He said that when he thinks of his peers in his hometown in Japan, he thinks that he can speak English better than he had expected; hence, he perceives a positive gap. However, when he compares himself against his peers in the U.S., he falls behind his expectation; thus, experience a negative gap. The 
direction of the gap he experiences changes, depending on the person against whom he compares himself.

In sum, as far as the "gap" construct rests on the assumption that the gap is stable, regardless of situations in which people are or without considering with whom one is comparing oneself, it is vulnerable to criticism. However, I still maintain that the examination of the "gap" posited a useful concept which has enabled a heuristic exploration of possible sources of FLA.

This research has many limitations which fall into one of two categories. Those due to the limitations of survey research in general and those due to the constructs and the questionnaire used in this research. Nevertheless, I believe that this research was able to produce useful findings and does provide useful suggestions for future researchers of SLA.

\section{Summary}

This final chapter finishes this thesis by concluding this research, providing some possible FLA reduction strategies for ESL language educators, and discussing some of the limitations of this research effort while offering suggestions for future SLA 
researchers. 


\section{REFERENCES}

Allen, J.L. \& Andriate, G. (1984a). Communication apprehension in bilingual non-native U.S. residents. Communication, 13, 39-48.

Allen, J.L. \& Andriate, G. (1984b). Communication apprehension in underprepared versus traditional college students. Communication Research Report, 1, 68-72.

Allen, J.L., O'Mare, J. \& Andriate, G. (1986a). Communication apprehension in bilingual non-native U.S. residents--Part II: Gender, second language experience and communication apprehension in functional contexts. World Communication, 15, 71-84.

Allen, J.L., O'Mare, J. \& Long, K.M. (1986b). Commutation competence, anxiety, avoidance behaviors and classroom experiences of nonnative English speakers on the US. Paper presented at the annual meeting of the Speech Communication association(72nd, Chicago, IL, November 13-16).

Bachman, L.F. (1976). Two measures of affective factors as they relate to progress in adult secondlanguage learning. Working Paper in Bilingualism, 10, 100-122.

Bachman, L.F. (1990). Fundamental consideration in language testing. Oxford:Oxford University Press.

Beaty, M. \& Andriate, G.S. (1985). Communication apprehension and general anxiety in the prediction of public speaking anxiety. Communication quarterly, 33 , 174-184.

Blanche, P. (1988). Self-assessment of foreign language skills: Implications for teachers and researchers. RELC Journal, 19, 75-93.

Bond, M.H. \& Cheung, M. (1984). Experimenter language choice and ethnic affirmation by Chinese trilinguals in Hong Kong. International Journal of Intercultural Relations, $\underline{8}, 347-356$.

Burgoon, J.K. \& Burgoon, M. (1974). Unwillingness to communicate, anomiaalienation, and communication apprehension as predictors of small group of communication. Journal of Psychology, 88, 31-38. 
Burgoon, J.K. \& Hale, J.L. (1983). A research note on the dimensions of communication reticence. Communication Quarterly, 31, 238-248.

Campbell, C.M. \& Ortiz, J. (1991). Helping students overcome foreign language anxiety: A foreign language workshop. In E.K. Horwitz \& D.J. Young (Eds.), Language anxiety: From theory and research to classroom implications, 153-168. NJ:Prentice-Hill.

Campbell, D.P. (1968). The strong vocational interest blank: 1927-1967. In P. McReynolds (Ed.), Advances in Psychological Assessment. CA:Science and Behavior Books Inc.

Chastain, K. (1975). Affective and ability factors in second language acquisition. Lanquage Learning, 25, 153-161.

Clement, R. (1987). Second language proficiency and acculturation: An investigation of the effects of language status and individual characteristics. Journal of Language and Social Psychology, 5, 271-290.

Clement, R., Dornyei, Z. \& Noels, K.A. (1994). Motivation, self-confidence, and group cohesion in the foreign language classroom. Lanquage Learning, 44, 147448 .

Clement, R., Gardner, R.C. \& Smith, P.C. (1977). Interethnic contact: Attitudinal consequences. Canadian Journal of Behavioral Science, 9, 205-215.

Cohen, Y. \& Norst, M.J. (1989). Fear, dependence, and loss of self-esteem: Affective barriers in second language learning among adults. RELC Journal, 20, 61-77.

Daly, J.A. (1978). The assessment of socialcommunication anxiety via self-reports: An comparison of measures. Communication Monograph, 45, 294-218.

Daly, J.A. (1991). Understanding communication apprehension: An introduction for language educators. In E.K. Horwitz \& D.J. Young (Eds.), Lanquage anxiety: From theory and research to classroom implications, 3-13. NJ : Prentice-Hill. 
Desrochers, A.M. \& Gardner, R.C. (1981). Second language acouisition: An investigation of a bicultural excursion experience. Quebec: International Center for Research on Bilingualism.

El-banna, I. (1989). Language anxiety and language proficiency among EFL/ESL learners at university level: An exploratory investigation. (ERIC Document Reproduction Service NO. ED 308 698).

Foss, K.A. \& Reitzel, A. C. (1988). A relational model for managing second language anxiety. TESOL Quarterly, 22, 437-454.

Ganschow, L., Sparks, R.L., Anderson, R., Javorshy, J., Skinner, S. \& Patton, J. (1994). Differences in language performance among high-, average-, and lowanxious college foreign language learners. The Modern Language Journal, 78, $41-55$.

Gardner, R.C., Moorcroft, R. \& MacIntyre, P.D. (1987). The role of anxiety in second language performance of language dropouts. (Research Bulletin No.657). Ontario:The University of Western Ontario.

Gardner, R.C., Smythe, P.C. \& Brunet, G.R. (1977). Intensive language study: Effects on attitude, motivation, and French achievement. Lanquage Learning, 27, $243-261$.

Gardner, R.C., Smythe, P.C. \& Clement, R. (1979). Intensive language study in bicultural milieu: An investigation of attitudes, motivation, and language proficiency. Lanquage Learning, 29, 305-320.

Hatch, E.M. (1991). The research manual: Design and statistics for applied linquistics. NY: Newbury House.

Hatch, E.M. \& Farhady, H. (1982). Research design and statistics for applied linquistics. Massachusetts:Newbury House Publishers, Inc.

Horwitz, K. E. (1989). Recent research on second language learners: Beliefs and anxiety. In D.K. Koike \& A.R.M. Simoes (Eds.), Texas papers in foreign lanquage education, 51-60. Texas:University of Texas. 
Horwitz, K. E. (1991). Preliminary evidence for the reliability and validity of a Foreign Language Anxiety Scale. In E.K. Horwitz \& D.J. Young (Eds.), Language anxiety: From theory and research to classroom implications, 37-39. NJ:Prentice-Hill.

Horwitz, K.E., Horwitz, M.B. \& Cope, J.A. (1991). Foreign classroom anxiety. In E.K. Horwitz \& D.J. Young (Eds.), Language anxiety: From theory and research to classroom implications, 27-36. NJ:Prentice-Hill.

Kleinmann, H. H. (1977). Avoidance behavior in adult language acquisition. Lanquage Learning, 27, 93107 .

Klopf, D.W. (1984). Cross-cultural apprehension research: A summary of pacific basin studies. In J.A. Daly \& J.C. McCroskey (Eds.), Avoiding communication, 157-172. CA: Sage.

Kulick, K.M. (1990). Foreign Language proficiency and the adult leanr. In Magnan (Ed.), Shifting the instructional focus to the learner. VT:The Northeast Conference on the Teaching of Foreign Language, Inc.

Larsen-Freeman, D. (1981). The "what" of second language acquisition. On TESOL '81, 107-128.

Leary, M.R. (1990). Anxiety, cognition \& behavior: In search of a broader perspective. Journal of Social Behavior and Personality, $\underline{5}, 39-44$.

Lebra, K. (1976). Japanese patterns of behavior. Honolulu: The University Press of Hawaii.

Lederman, L.C. (1983). High communication apprehensives talk about communication apprehension and its effects on their behavior. Communication ouarterly, $\underline{31}, 233-237$.

Lucas, J. (1984). Communication Apprehension in the ESL classroom: getting our students to talk. Foreign Language Annual, 17, 593-598. 
MacIntyre, P.D. \& Gardner, R.C. (1988). The measurement of anxiety and applications to second language learning: An annotated bibliography. Ontario:The University of Western Ontario.

MacIntyre, P.D. \& Gardner, R.C. (1989). Anxiety and second language learning: Toward a theoretical clarification. Language Learning, 39, 251-275.

MacIntyre, P.D. \& Gardner, R.C. (1991a). Investigating language class anxiety using the focused essay technique. The Modern Language Journal, 75, 298304 .

MacIntyre, P.D. \& Gardner, R.C. (1991b). Methods and results in the study of anxiety and language learning: A review of literature. Language Learning, 41 . 85-117.

MacIntyre, P.D. \& Gardner, R.C. (1994). The subtle effects of language anxiety in cognitive processing in the second language. Language Learning, 44, 283-305.

McCroskey, J. C. (1970). Measure of communicationbound anxiety. Speech Monograph, 37, 269-277.

McCroskey, J. C. (1977). Oral communication apprehension: A summary of recent theory and research. Human Communication Research, 4 , 78-96.

McCroskey, J. C. (1978). Validity of the PRCA as an index of oral communication apprehension. Communication Monograph, 45, 192-203.

McCroskey, J. C. (1984). The communication apprehension perspective. In J.A. Daly \& J.C. McCroskey (Eds.), Avoiding communication. CA: Sage.

McCroskey, J. C. (1985). A trait perspective on communication competence. Paper presented at the annual meeting of the international communication association (35th, Honolulu, May 2-27).

McCroskey, J.C., Frayer, J.M. \& Richmond, V.P. (1985a). Don't speak to me in English: Communication apprehension in Puerto Rico. Communication Quarterly, 33, 185-192. 
McCroskey, J.C., Gudykunst, W.B. \& Nishida, T. (1985b). Communication apprehension among Japanese students in native and second language. Communication Research Reports, $\underline{2}, 11-16$.

McCroskey, J.C. \& McCroskey, L.L. (1986). Selfreport as an approach to measuring communication competence. Paper presented at the annual meeting of the central state speech association (Cincinnati, OH, April 17-19).

McCroskey, J.C. \& Richmond, V.P. (1987). Willingness to communicate and interpersonal communication. In J.C. McCroskey \& J.A. Daly (Eds.), Personality and interpersonal communication, 129-156. CA:Sage.

Mehrabian, A. (1971). Silent messages. CA: Wadsworth.

Miller, G. (1953). What is information measurement? American Psychologist, 9, 3-11.

Norusis, M.J. (1988). SPSS/PC+ student ware. IL: SPSS Inc.

Norusis, M.J. (1992). SPSS/PC+ base system user's guide. IL: SPSS Inc.

Philips, E.M. (1992). The effects of language anxiety on students' oral test performance and attitudes. The Modern Language Journal, 76, 14-26.

Price, M. L. (1991). The subjective experience of foreign language anxiety: Interviews with highly anxious students. In E.K. Horwitz \& D.J. Young (Eds.), Lanquage anxiety: From theory and research to classroom implications, 101-108. NJ:Prentice-Hill.

Pucel, J. \& Stocker, G. (1982). A nonverbal approach to communication: A cross-cultural study of stress behaviors. Paper presented at the Annual Meeting of the Speech communication Association (68th, 4-7).

Rogers, T. \& Izutsu, S. (1980). The Japanese. In J.F. McDermott, Jr., W.S. Teng \& T. Martzki (Eds.), People and cultures in Hawaii: A psychocultural profile. Honolulu:University of Hawaii Press. 
Sanchez-Herrero, S.A. \& Sanchez, M.D.P. (1992). The predictive validation of an instrument designed to measure student anxiety in learning a foreign language. Educational and Psychological Measurement, 51, 961-966.

Scovel, T. (1978). The effects of affect on foreign language learning: A review of the anxiety research. Lanquage Learning, 28, 129-141.

Seilger, H.W. \& Shohamy, E. (1989). Second language research methods. Oxford: Oxford university Press.

Spielberger, C.D. (1983). Manual for state-trait anxiety inventory. CA:Consulting Psychologist Press.

Steinberg, F.S. \& Horwitz, E.K. (1985). The effects of induced anxiety on the denotative and interpretive content of second language speech. TESOL Quarterly, 20, 131-136.

Tucker, G.R., Hamayan, E. \& Genesee, F.H. (1976). Affective, cognitive and social factors in secondlanguage acquisition. The Canadian Lanquage Review, 32, 214-226.

Twyford, C.M. (1987). Age-related factors in second language acquisition. New Focus, NCBE Occasional Papers in Bilingual education, 2 .

Verhoeven, L. \& H.A.L. de Jong, J. (1992) . Modeling and assessing language proficiency. In Verhoeven, L. \& H.A.L. de Jong, J. (Eds.), The construct of language proficiency: Applications of psychological models to lanquage assessment, 3-19. Philadelphia:John Benjamin Publishing Co.

Williams, K. (1991). Anxiety and formal/ foreign language learning. RELC Journal, 22, 19-28.

Yamamoto, N. (1991). Effects of setting on Japanese ESL students' interaction patters. Unpublished Master's thesis, Portland State University, Oregon.

Young, D. J. (1990). An investigation of students' perspectives on anxiety and speaking. Foreign Language Annuals, 23, 539-553. 
Young, D. J. (1991). Creating a low-anxiety classroom environment: What does the language anxiety research suggest? The Modern Lanquage Journal, 75, 425439 .

Young, D. J. (1992). Language anxiety from the foreign language specialists' perspective: Interviews with Krashen, Omaggio Hadley, Terrell, and Rardin. Foreign Language Annuals, 25, 152-172.

Zimbardo, P. (1977). Shyness-the people phobia. Today's Education, 66, 47-49. 
APPENDIX A

SUBJECTS' DEMOGRAPHIC INFORMATION 
The Subjects' Demographic Information:

Their Age, Gender, Status in School and Year(s) of Residence

AGES OF THE SUBJECTS

\begin{tabular}{|c|c|c|}
\hline & Frequency & Percent \\
\hline $18-23$ & 155 & 66.8 \\
\hline $24-29$ & 50 & 21.6 \\
\hline \multirow[t]{2}{*}{30 or more } & 27 & 11.6 \\
\hline & Total & 100.0 \\
\hline
\end{tabular}

GENDER OF THE SUBJECTS

\begin{tabular}{|c|c|c|c|}
\hline & & Frequency & Percent \\
\hline Female & & 150 & 64.7 \\
\hline \multirow[t]{2}{*}{ Male } & & 82 & 35.3 \\
\hline & Total & 232 & 100.0 \\
\hline
\end{tabular}

STATUS OF THE SUBJECTS IN SCHOOL

\begin{tabular}{|c|c|c|}
\hline & Frequency & Percent \\
\hline ESL Only & 61 & 26.4 \\
\hline ESL + Regular & 12 & 5.2 \\
\hline Exchange Program & 41 & 17.7 \\
\hline Undergraduate & 89 & 38.5 \\
\hline Graduate & 19 & 8.2 \\
\hline Others & 9 & 3.9 \\
\hline Total & 231 & 100.0 \\
\hline
\end{tabular}


THE SUBJECTS' YEAR(S) OF RESIDENCE IN ENGLISH SPEAKING PLACES

\begin{tabular}{|c|c|c|c|}
\hline & & requency & Percent \\
\hline Less than 1 & & 105 & 45.3 \\
\hline $1-3$ & & 57 & 24.6 \\
\hline $4-7$ & & 58 & 25.0 \\
\hline \multirow[t]{2}{*}{8 or more } & & 12 & 5.2 \\
\hline & Total & 232 & 100.0 \\
\hline
\end{tabular}


APPENDIX B

COVER LETTER AND QUESTIONNAIRE IN ENGLISH AS ADMINISTERED TO THE SUBJECTS 


\section{Cover Letter and Questionnaire in English}

\section{To Japanese Student;}

Hello. I am Sawako Yoshikawa. I am a graduate student in the department of Applied Linguistics at Portland State University (PSU). I am working on my thesis under professor Brown, and I would like to ask you for your assistance in my research. The purpose of my study to identify and explore some possible problems among Japanese learners of English regarding their oral production. You may not receive any direct benefits from taking part in this study; however, this study may help others in the future. Also, my thesis will be kept in the PSU library, so you may see the results of the study if you are interested.

This questionnaire is composed of 34 questions which will elicit the views of Japanese learners of English on their speaking experiences and eight personal questions, such as your age and gender. It will take approximately 10 to 15 minutes to complete. All information gathered will be anonymous.

This research is voluntary and it is your choice whether you participate in this study or not. If you decide not to take part in this research. or choose to withdraw from this survey at any time, it will NOT affect 
your grades or relationship with the school which you attend or with PSU.

If you would like to take part in this research, please fill out the survey on the next page and mail it back to me using the envelope attached to this survey. If somebody is collecting this survey, please give this to the person in charge.

If you have any concerns or questions about this study, please contact the chair of the Human subject Research Review and Sponsored Projects. 105 Neuberger Hall, Portland State University, 503/725-3417. 
This questionnaire is composed of four sections. In sections 1 and 2 , you will be asked some questions concerning your experience with English, and in section 3, concerning with Japanese. Lastly, in section 4 you will be asked some personal questions, such as your age or gender.

In answering sections 1 and 3 , you will be asked to rate statements on a scale of whether you 1) Strongly Agree, 2) Agree, 3) Undecided, 4) Disagree and 5) Strongly Disagree. In answering section 2, you will be asked some questions on a scale of 1-5, 1 being poor and 5 being Fluent. There are no right or wrong answers. Just record your first impressions.

In the following examples are provided in order to show how to answer the questions in this survey.

Example A Question: I like dogs. Strongly Agree _ $:$ _ $: \underline{\downarrow}: \ldots$ : _ Strongly Disagree In this example, the scale indicates that you do not like dogs, but do not dislike dogs.

Example B Question: How well do you speak Russian? Poor _ : _ : _ $: \underline{V}:$ _ Fluent

In this example, the scale indicates that you speak Russian well, but not very fluently.

Section 1: Please rate the following 10 statements regarding your experience with English.

1. I look forward to expressing myself in English in a class of around 20 students.

Strongly Agree _ : _ : _ : _ : _ Strongly Disagree

2. I am afraid of expressing myself in English in a group of 4-5 people.

Strongly Agree _ $:$ _ $:$ _ : _ $:$ _ Strongly Disagree

3. I look forward to an opportunity to speak in English in public.

Strongly Agree _ $:$ _ $:$ _ $:$ _

4. When I speak English, I am at loss for words on the platform.

Strongly Agree _ : _ _ _ _ _ _ _ _ Strongly Disagree 
5. I always avoid speaking in English in public if possible.

Strongly Agree _ : _ : _ : _ _ _ Strongly Disagree

6. I feel that I am more fluent when speaking to people in English than most people are.

strongly Agree - : _ : _ : : -

Strongly Disagree

7. I like to get involved in group discussions in English where there are 4-5 people are present.

strongly Agree : : : : :

Strongly Disagree

8. When I speak English, I dislike using my body and voice expressively.

Strongly Agree _ : _ : _ : _ : _ Strongly Disagree

9. When I talk to a classmate one to one in English, I am afraid to speak up in conversations.

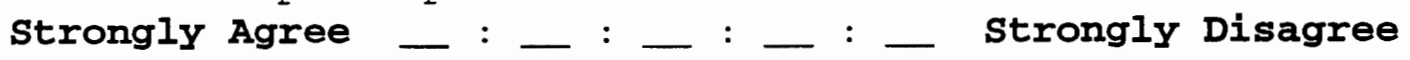

10.I would enjoy presenting a speech in English on a local TV show.

Strongly Agree _ $:$ _ : _ : _ : _ Strongly Disagree

Section 2: The following 14 questions will ask you about how well you think or how other people think your speaking ability is. Underlines in the questions are used in order to make the questions clearer.

1. How well do you thin you speak English at this point?

Poor

\section{Fluent}

2. Suppose you are discussing your paper with your instructor in his/her office, how well do you think you would be able to speak English in that context?

Poor _ _ : _ : _ : _ : _ Fluent

3. Considering the length of time you have spent learning English, how well do you think you should be able to speak English at this point?

Poor _ : _ : _ : _ : _ Fluent

4. How well do you think you should be able to speak English at this point?

Poor _ : _ : _ : _ : _ Fluent 
5. Considering the length of time have spent living an English speaking place(s), how well do you think you should be able to speak English at this point?

$$
\text { Poor _ : _ : _ : _ : _ Fluent }
$$

6. If a person whose native tongue is English starts talking to you on the street, how well do you think you respond in English?

Poor _ : _ : _ : _ : _ Fluent

7. How do you think your instructor would rate your English Speaking ability?

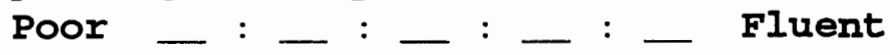

8. How do you think people who have close contact with you (e.g., friends and classmates) expect that you should speak English at this point?

$$
\text { Poor _ : _ : _ : _ : _ Fluent }
$$

9. How do you think Americans expect that your speaking ability of English should be?

$$
\text { Poor _ : _ : _ : _ : _ Fluent }
$$

10. If a person whose native tongue is NOT English starts talking to you on the street, how well do you think you respond in English?

Poor _ : _ : _ : _ : _ Fluent

11. Considering your ability to learn a foreign language, how well do you expect you should be able to speak English at this point?

$$
\text { Poor _ : _ : _ : _ : _ Fluent }
$$

12. When you are talking about your personal matters with your friend at a coffee shop, how well you think you speak English?

$$
\text { Poor _ : _ : _ _ _ _ Fluent }
$$

13. How well do you expect you should speak English at this Point?

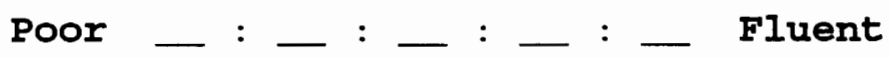

14. How do you rate your speaking ability in English is? Poor _ : _ : _ : _ : _ Fluent 
Section 3: Please rate the following 10 statements regarding your experience with Japanese.

1. I look forward to expressing myself in Japanese in a class of around 20 students.

Strongly Agree _ _ _ _ : _ _ _ _ : _ Strongly Disagree

2. I am afraid of expressing myself in Japanese in a group of 4-5 people.

Strongly Agree __ : _ _ _ _ : _ _ _ _ Strongly Disagree

3. I look forward to an opportunity to speak in Japanese in public.

Strongly Agree _ : _ : _ $:$ _ $:$ _ Strongly Disagree

4. When I speak Japanese, I am at loss for words on the platform.

Strongly Agree _ _ : _ : _ _ _ _ : _ Strongly Disagree

5. I always avoid speaking in Japanese in public if possible.

Strongly Agree _ _ _ _ : _ : _ : _ Strongly Disagree

6. I feel that I am more fluent when speaking to people in Japanese than most people are.

Strongly Agree _ _ _ _ : _ _ _ _ : _ Strongly Disagree

7. I like to get involved in group discussions in Japanese where there are 4-5 people are present.

Strongly Agree _ _ _ _ : _ _ _ _ _ _ Strongly Disagree

8. When I speak Japanese, I dislike using my body and voice expressively.

Strongly Agree _ _ _ _ : _ _ _ _ : _ Strongly Disagree

9. When I talk to a classmate one to one in Japanese, I am afraid to speak up in conversations.

Strongly Agree _ _ _ _ : _ _ : _ : _ _ Strongly Disagree

10. I would enjoy presenting a speech in Japanese on a local TV show.

Strongly Agree _ _ _ _ : _ _ _ _ : _ Strongly Disagree 
Section 4: Please answer the following 8 personal questions.

1. How old are you?

$18-23$

24-29

- 30 and over

2. What is your gender?

\section{Female}

Male

3. What is your status at school?

ESL only

- ESL and regular class (undergraduate and/or graduate)

- Exchange program

- Undergraduate

- Others

4. How many year(s) have you spent living in English speaking places?
L less than 1 year
1-3 years
- $4-7$ years
- 8 years or more

5. How many year(s) have you spent learning English

(including private lessons outside of school)?

less than 6 year

- 7-10 years

- 11-15 years

- 15 years or more

6. Do you think that there is a gap between how well you think you should be able to speak English by this time and

how well you think you can actually speak?

Y Yes

No

I don't know.

If you answered Yes to question 6 , please go to the 
following questions.

7. Which one in the following two sentences better describes the gap mentioned in question 6?

- I CAN speak English better than I had expected.

- I can NOT speak English better than I had expected.

8. Please rate how big the gap is.

$$
\text { Minimal }
$$

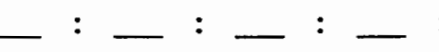
- Maximal

Thank you very much 
APPENDIX C

COVER LETTER AND QUESTIONNAIRE IN JAPANESE 
日本人学生のみなさんへ

こんにちは。私はポートランド州立大学 (PSU) の修士課程で応用言語 学を勉強している吉川佐和子といいます。現在私はブラウン教授の指導下で修士 論文のため調查を行つており、その調查のため日本人学生のみなさんに協力をお 願いしています。

この調查は、アンケート形式で、英語を話すことに関する巳本人の意見や 経験を調べるものです。この研究の最終目標は、日本人が英語を話す時経験する 諸問題の原因を追求することです。この調査に協力することでアンケート参加者 が直接利益を受けることはないかも知れませんが、この調相結果は今後の英語学 習者の抱える問題改善に役立つと思われます。また、私の論文はPSU図書館に 保管される予定ですので、調査結果に興味のある方はこ覽になることができます。 アンケートは調查に直接関係する340質問と、アンケート参加者の性別、 年齢、学年などの個人的な情報を尋格る8つの質問、計 42 項目によつて構成さ れており、参加者はすべて匿名で処理されます。所要時間は約 15 分と思われま す。

この調查は任意参加ですので、この調査に参加するしないを決めるのは完 全にあなたの自由です。あなたがこの調查に最後まで協力できなかつたり、ある アンケートの質問に答えなかつたとしても、ボートランド州立大学、もしくは現 在通つている学校、クラス、成樍等に一切影響することはありません。

もしあなたがこの調査に協力していたたけるようでしたら、次のページか ら始まるアンケートにお答え下さい。そしてそのアンケートを付属の封筒で私、 吉川佐和子までお送り下さい。もし係りの方がこのアンケートを集めて下さつて いる場合はその方に提出して下さい。

$$
\text { こ勐力よろしくお願いします。 }
$$

この調查に関して質問、意見などありましたら下記までこ連絡下さい。
$\mathrm{Ch}$ a i $r$ of the Human Subject Research Review Commit tee. Sponsored Projects. 105 Neuberger Hall, Port land State University, (503) 725-3417 
アンケートは全 4 部から構成されています。1部と民部では英語を話すことについての、そし

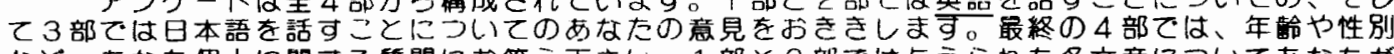
なと、あなた個人に関する質問にお答え下さい。1部とる部では与えられた各文章についてあなたが とう思うか、下記の5う(1·強くそう思う、2 2 そう思う、3・决めかねる、4・そう思わない、 5 .全然そう思わない)の中から最も適当たと思われる表現を選んでくたさい。2部ては、各質問に ついて最も適当たと思われる表現を1の不手から5の流啺（りゅうちょう）までの5段晆の中から選 んで下さい。このアンケートの回答には、正解や不正解はありません。あなたが質問を読んで最初に 思つた事を記入して下さい。下記の回答例を参照ください。

1 部とろ 部の回答例

私は犬が好きです。

強くそう思う - - : - - - : -

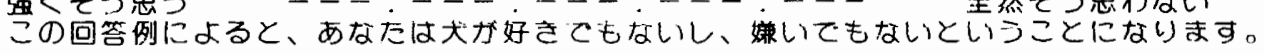

2部の回答例 あなたはロシア語がとれくらいうまく話せると思いますか？

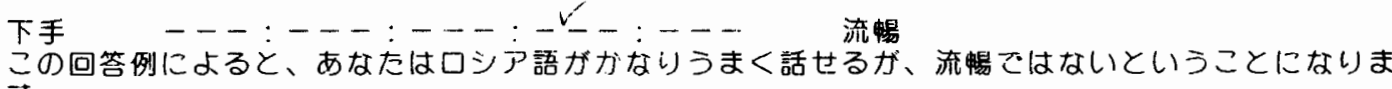
g。

第1部、下記の10問はあなたが烡語を話す時のことについて質問します。

1 ・私は20人程度の学生が出席しているクラスで自分の意見を英語で進んで述べる方たと思う。

強くそう思う - - - :-- : - - : - - : - - 全然そう思わない

2.4-5人程度のフループの中で自分の意見を英語で進んで述ぺるのは大の苦手である。

強くそう思う - - : - - : - - : - - : - - 全然そう思わない

3・もし公の場で英語で話す機会を与えらたなら、私はその機会を待ちどうしく思うタイプたと思う。

強くそう思う - - - - - : - - : - - : - - - 全然そう思わない

4・もし英語てスピーチをするために演台に立つたとしたら、㗚につまってしまうような気がする。

強くそう思う - - : - - : - - : - - : - - 全然そう思わない

5 ・公の場で英語で話すのはできるたけ避けるようにしている。

这くそう思う - - : - - : - - : - - : - - 全然そう思わない

6・他人に比べ、私はより流蝪に英語で会話を交才していると思う。

強くそう思う - - : - - : - - : - - - :- - 全然そう思わない

7 . 私は 4-5人程度のフループの中て、英語てティスカッションをするのが好きた。

強くそう思う - - : - - : - - : - - : - - - 全然そう思わない

8 ・私は英語て話す時に身振りや声を表現豊かに使うのが嫌いである。

強くそう思う - - : - - : - - : - - : - - 全然そう思わない

9 ・英語を使つてクラスメイトと 1 対 1 て会話を交わすのは苦痛である。

強くそう思う - - - : - - : - - : - - : - - 全然そう思わない

10 ・地元のテレピ番組で英語でスピーチをする機会を与えられたなら、喜んでると思う。

強くそう思う - - : - - : - - :- - : - 全然そう思わない 


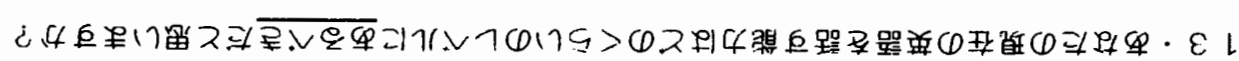

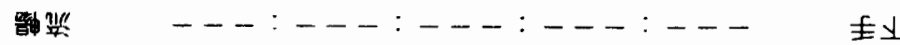

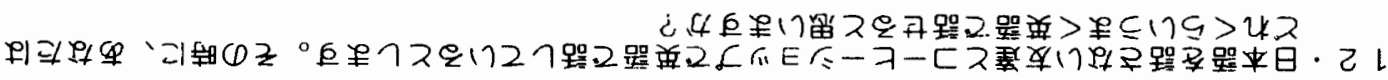

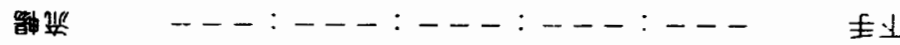

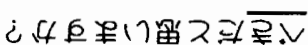

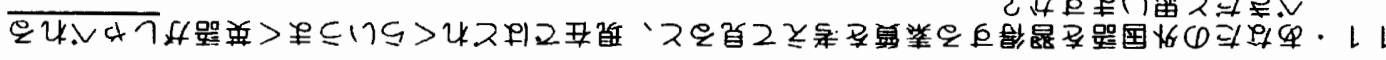

知紧 - - - : - - : - - : -

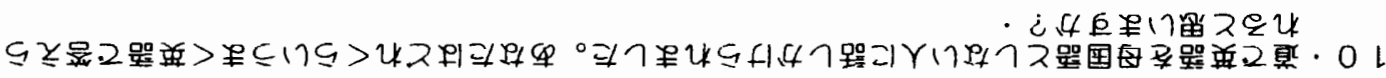

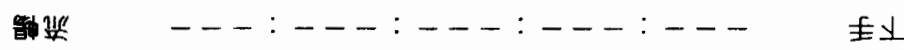

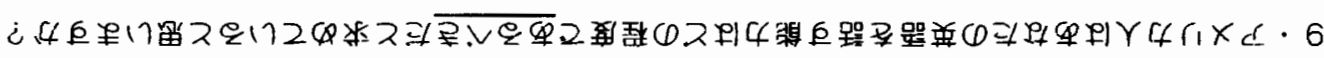

㩆篦 - - : - - : - - : - : - - 主上

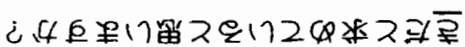

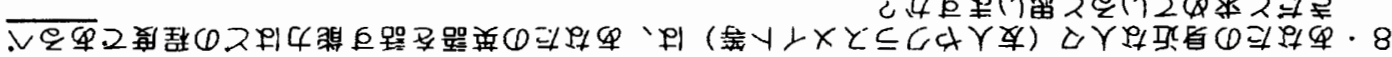

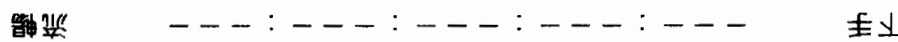

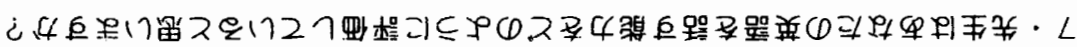

㩆紧 - - : - - : - - : - - : - - 毛上

¿4⿻上丨䞏入

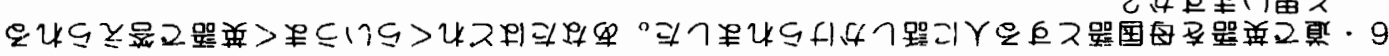

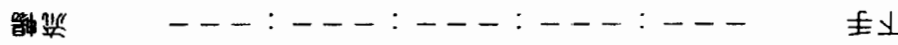

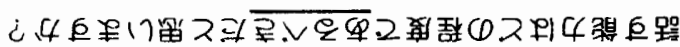

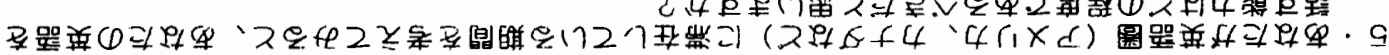

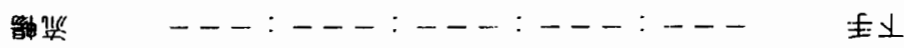

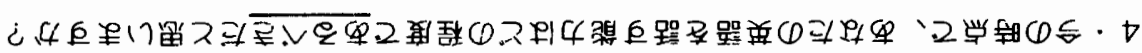

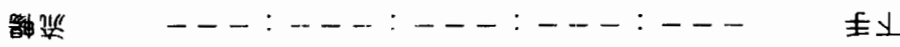

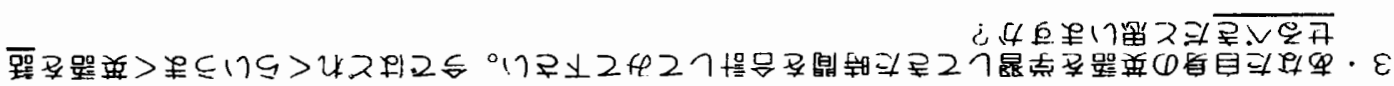

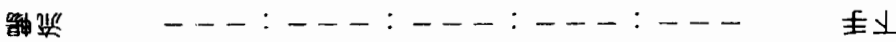

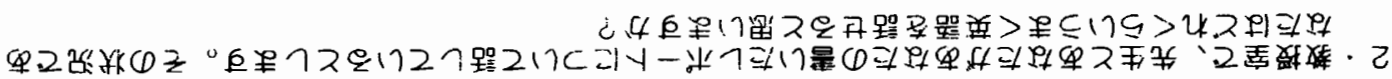

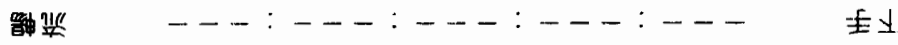

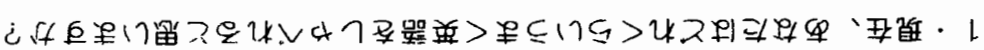

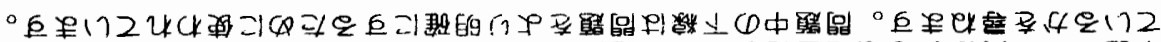

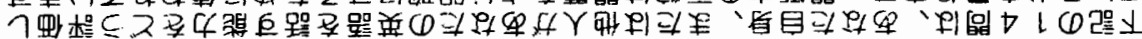

踖已雪 
14 ・現在の実力をあなた自身で評洒してみてください。どの程度英語が話せると思いますか？

下手 - - : - - : - - : - - : - - 流蝪

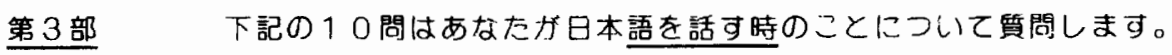

1 ・私は20人程度の学生が出席しているつラスで自分の意見を日本語で進んて述べる方たと思う。

強くそう思う - - : - - : - - : - - : - - 全然そう思わない

2.4-5人程度のフループの中で自分の意見を日本語で進んで述べるのは大の苦手である。

強くそう思う - - : - - - - - - - - : - - 全然そう思わない

3・もし公の場て日本語で話す機会を与えらたなら、私はその機会を待ちどうしく思うタイフたと思 強くそう思う - - : - - : - - : - - : - - 全然そう思わない

4 ・もし日本語でスピーチをするために演台に立つたとしたら、言葉につまつてしまうような気がす
る。 強くそう思う - - : - - : - - : - - : - - 全然そう思わない

5・公の場で日本語で話すのはできるたけ避けるようにしている。

強くそう思う - - : - - : - - : - - :- - 全然そう思わない

6・他人に比ぺ、私はよりなめらかに日本語で会話を交わしていると思う。

虺くそう思う - - : - - : - - : - - : - - 全然そう思わない

7 ・私は 4-5人程度のフループの中て、日本語でディスカッションをするのが好きた。

強くそう思う - - : - - : - - : - - : - - 全然そう思わない

8・私は日本吾で話す時に身振りや声を表現豊かに使うのが嫌いである。

強くそう思う - - : - - : - - : - - : - - 全然そう思わない

$9 \cdot$ 日本語を使つてクラスメイトと1対 1 て会話を交わすのは苦痛てある。

強くそう思う - - : - - :--- :--- :-- - 全然そう思わない

10 ・地元のテレピ番組で日本語でスヒーチをする譏会を与えられたなら、喜んですと思う。

強くそう思う - - : - - : - - : - - : - - 全然そう思わない

\section{第 4 部}

1 ・あなたの年路は?

$--18 \sim 23$

$--24 \sim 29$

- $30 \sim 40$

- 4 0才以上

2・あなたの性別は?

- - 女性

- - 男性 
あなたの学年は?

- - ESレプロケラムのみ

- -ESLプロララムと大学又は、大学院の授業両方を受講中

一一日本の大学に在学中たが、交換留学等によってESしプロクラムや大学又は、大学院の授業 を受講中

- 一大学生(ポストバックも含む)

- 一大学院生

- -之の他

$4 \cdot$ 何年間英語圈に滞在していますか？

--1 年以内

$-1 \sim 3$ 年

$--4 \sim 7$ 年

--8 年以上

5 ・何年間烡語を学習してきましたが?

--6 年以内

$--7 \sim 10$

$-11 \sim 15$

-16 年以上

6・あなたが現在習得しているべきたと思う英語を話す能力とあたなの実際の英語を話す能力にはギ ヤップガあると思いますが?

- -はい

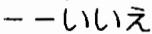

- 一分からない

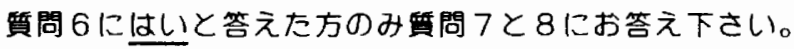

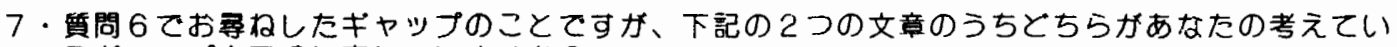
るギャップを正確に表していますか?

一一私は自分が予想していたほとうまく英語をしゃべれないと思う。

一一私は目分が思つていたよりもうまく英語をしゃべれるようになつたと思う。

8・引き続きギャップについての質問ですが、そのギャップの大きさはとれくらいか下の5つの中が ら選んでたい。

たいした違いはない

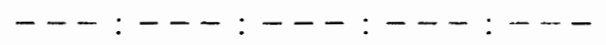

とても大きく違う

こ協力ありがとうこさいました 


\section{APPENDIX D}

QUESTION ITEMS CATEGORIZED ACCORDING TO CONSTRUCTS 
The FLA and NTA Constructs

(used in either English speaking or

Japanese speaking contexts)

1. I look forward to expressing myself in a class of around 20 students.

Strongly Agree _ _ _ _ : _ : _ _ _ _ strongly Disagree

2. I am afraid of expressing myself in a group of 4-5 people.

Strongly Agree __ : _ _ _ _ : _ : _ Strongly Disagree

3. I look forward to an opportunity to speak in public.

Strongly Agree _ _ : _ _ _ _ _ _ : _ Strongly Disagree

4. I am at loss for words on the platform.

Strongly Agree _ _ _ _ : _

5. I always avoid speaking in public if possible.

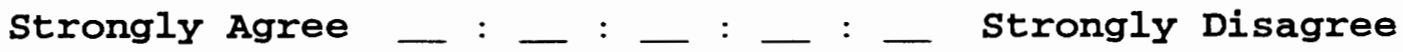

6. I feel that I am more fluent when speaking to people than most people are.

Strongly Agree _ _ _ _ _ _ : _ : _ Strongly Disagree

7. I like to get involved in group discussions where there are 4-5 people are present.

strongly Agree _ _ _ _ : _ : _ : _ Strongly Disagree

8. I dislike using my body and voice expressively.

Strongly Agree _ _ _ _ _ _ _ _ _ _ _ Strongly Disagree

9. When I talk to a classmate one to one, I am afraid to speak up in conversations.

Strongly Agree _ _ _ _ _ _ : _ _ _ _ Strongly Disagree

10. I would enjoy presenting a speech on a local TV show. Strongly Agree _ _ _ _ : _ _ _ _ _ _ Strongly Disagree

\section{Self-Perceived Oral English Proficiency}

How well do you think you speak English at this point?

$$
\text { Poor _ _ _ _ _ _ : _ : _ F Fluent }
$$


How do you rate your speaking ability in English?

Poor _ _ _ _ : _ : _ _ _ _ Fluent

\section{The gapsize between the subjects' self-perceived and self-expected oral English proficiency}

Do you think that there is a gap between how well you think you should be able to speak English by this time and how well you think you can actually speak?

Yes
No
I don't know.

If you answered Yes to the above question, please go to the following questions.

Which one in the following two sentences better describes the gap mentioned in question 6 ?

- I CAN speak English better than I had expected.

- I can NOT speak English better than I had expected.

Please rate how big the gap is.

Minimal _ : _ : _ : _ : _ Maximal 
APPENDIX E

FACTORS INFLUENCING VALIDITY CHECKLIST HATCH AND FARHADY 1982 


\section{Factors Influencing Validity Checklist}

There are many factors which could influence the validity of test results. When you select a test (or when you construct one yourself), you ought to consider these factors very carefully.

Factors which influence the validity of test results include:

1. Under directions on the test (the Ss may, in fact, know the material, but do not understand how to do the task, so the results are not valid)

2. Vocabulary or syntax (assuming this is not the focus of the test) may be too difficult (the Ss may, in fact, know, the material but not be able to do the task, so the results are not valid)

3. Inappropriate level of difficulty of test items (the test may not test the concepts at the right level, and so the Ss may perform the task in a way which does not represent a valid assessment of abilities.

4. Poorly constructed test items

5. Ambiguity

6. Test items inappropriate for the purpose of the test 7, Test does not have enough items for objectives being tested

8. Improper arrangement of items (initial sequence of difficult items may cause ss to give up when they could to later items 
9. Identifiable pattern of answers (Ss can get the items right without knowing answers). 